\title{
Optimization of overexpression of a chaperone protein of steroid C25 dehydrogenase for biochemical and biophysical characterization
}

Ewa Niedzialkowska ${ }^{1,6^{*}}$, Beata Mrugała ${ }^{1}$, Agnieszka Rugor ${ }^{1}$, Mateusz P. Czub ${ }^{2,5}$, Anna Skotnicka ${ }^{3}$, Julien J. H. Cotelesage ${ }^{4}$, Graham N. George ${ }^{4}$, Maciej Szaleniec ${ }^{1}$, Wladek Minor ${ }^{5}$, Krzysztof Lewiński $^{2}$

1- Jerzy Haber Institute of Catalysis and Surface Chemistry, Polish Academy of Sciences, Niezapominajek 8, 30239 Krakow, Poland

2- Faculty of Chemistry, Jagiellonian University, Ingardena 3, Krakow, 30060, Poland

3- Faculty of Agriculture and Economics, University of Agriculture in Krakow, Mickiewicza 21, 31120 Krakow, Poland

4- Molecular and Environmental Sciences Group, Department of Geological Sciences, University of Saskatchewan, Saskatoon, SK S7N 5E2, Canada

5- Department of Molecular Physiology and Biological Physics, University of Virginia, 1340 Jefferson Park Avenue, Charlottesville, VA 22908, USA

* - corresponding author

mailing address: Jerzy Haber Institute of Catalysis and Surface Chemistry, Polish Academy of Sciences, Niezapominajek 8, 30239 Krakow, Poland

email address: nceniedz@cyf-kr.edu.pl

telephone number: +48 1263951 58; fax number: +48124251923

\section{Key words}

chaperone protein; molybdenum cofactor; thermofluor shift assay; molybdoenzymes

\section{Abbreviations}

Moco - molybdenum cofactor; TSA - thermofluor shift assay; EXAFS - extended X-ray absorption fine structure; SEC - size exclusion chromatography; HPLC - high performance liquid chromatography; FPLC fast protein liquid chromatography; ICP-MS - inductively coupled plasma mass spectrometry; bis-MGD bis-molybdopterin guanine dinucleotide; S25DH - steroid C25 dehydrogenase; ITC - isothermal titration calorimetry; GDP - guanosine diphosphate; DTT - dithiothreitol

6 - Present address: Department of Molecular Physiology and Biological Physics, University of Virginia, 1340 Jefferson Park Avenue, Charlottesville, VA 22908, USA; email address: ekn7f@virginia.edu 


\section{ABSTRACT}

Molybdenum is an essential nutrient for plant, bacteria and animal metabolism. Molybdoenzymes are involved in nitrogen assimilation and oxidoreductive, detoxification and bioconversion reactions of environmental, industrial, and pharmaceutical interest. Molybdoenzymes contain a molybdenum cofactor (Moco) which is a pyranopterin heterocyclic compound that binds a molybdenum atom via a dithiolene group. Because Moco is a large and complex compound deeply buried within protein, molybdoenzymes are accompanied by their private chaperone protein responsible for the cofactor's insertion into the enzyme and the enzyme's maturation. An efficient recombinant expression and purification of both Moco-free and Moco-containing molybdoenzymes and their chaperones is of paramount importance for fundamental and applied research related to molybdoenzymes. In this work, we focused on a D1 protein annotated as a chaperone of steroid C25 dehydrogenase (S25DH) from Sterolibacterium denitrificans Chol-1S. The D1 protein is presumably involved in maturation of S25DH engaged in oxygen-independent oxidation of sterols. As this chaperone is thought to be a crucial element that ensures insertion of Moco into the enzyme and, consequently, proper folding of S25DH, optimization of its expression is the first step towards development of recombinant expression and purification methods for $\mathrm{S} 25 \mathrm{DH}$. We have identified common E. coli strains and conditions for both expression and purification that allow us to selectively produce Moco-containing and Moco-free chaperones. We have also characterized the Moco-containing chaperone by EXAFS and HPLC analysis, and identified conditions that stabilize both forms of the protein. The protocols presented here are efficient and result in protein quantities sufficient for biochemical studies. 


\section{INTRODUCTION}

Molybdoenzymes use a wide range of substrates to catalyze diverse redox reactions in bacteria, plants, and animals. Bacterial molybdoenzymes are responsible, for example, for anaerobic respiration, degradation of aromatic and aliphatic hydrocarbons [1] or oxochlorate [2, 3], and arsenate [4] or sulfate metabolism [5]. In plants molybdoenzymes take part in nitrate assimilation (nitrate reductases), purine catabolism (xanthine dehydrogenase) [6], hormone synthesis (aldehyde oxidase) or detoxification mechanism (sulfite oxidase) [7]. Similarly, in humans several molybdoenzymes have been identified so far including xanthine oxidoreductase [8], sulfite and aldehyde oxidase [9], or mitochondrial amidoxime reducing components 1 and 2 (mARC1 and $m A R C 2)[10,11]$. The plethora of substrates capable of being utilized by molybdoenzymes prompted researchers to investigate their potential applications in bioremediation [1, 2], agriculture [12], drug synthesis and medicine [13].

The crucial component of molybdoenzymes is an organometallic structure called molybdenum cofactor (Moco) [14] that forms the active site of molybdoenzyme. In Moco a pterin referred to as molybdopterin (MPT) serves as a scaffold for a molybdenum atom. Moco must be synthesized de novo in a cell, and the process of Moco synthesis is complex, involving several synthesis pathways and facilitated by multiple proteins [15]. A cofactor moiety isolated from a protein is very unstable, and currently the Moco precursors are obtained either through chemical synthesis or isolation and subsequent derivatization of Moco from natural sources [16].

Proteins belonging to the DMSO reductase family contain the bis-molybdopterin guanine dinucleotide (bis-MGD) type of Moco. In bis-MGD, the molybdenum atom is coordinated through two dithiolene groups of two MGD moieties [17-19]. In E. coli, the in vivo process of production of bis-MGD cofactor consists of four main steps: a) conversion of GTP into cyclic pyranopterin monophosphate (cPMP) by $S$-adenosyl methionine (SAM)-dependent radical enzymes [20] and cyclic pyranopterin monophosphate synthase accessory protein, b) insertion of sulfur and formation of molybdopterin (MPT) by MPT synthase [21, 22], c) insertion of molybdenum, which is sequestrated in the form of a molybdate oxyanion $\left(\mathrm{MoO}_{4}{ }^{2-}\right)$ [23] into MPT by molybdopterin adenylyltransferase (MogA) [24] and molybdopterin molybdenumtransferase (MoeA) [18] and d) further modification of Moco to form a dinucleotide derivative of Moco, the MPT-guanine dinucleotide (MGD) cofactor.

The malfunctions of molybdoenzymes due either to mutations in the enzymes or insufficient molybdenum cofactor production can cause various diseases in humans. For example xanthinuria can be caused by a mutation in the gene coding for xanthine dehydrogenase [25], and a molybdenum cofactor deficiency (MoCD) type $A$ is a rare metabolic disease caused by mutations in genes coding for proteins involved in a cofactor synthesis. Improper functioning of molybdoenzymes can result in increased levels of metabolites (sulfites) that are toxic if not broken down. MoCDs are linked to brain dysfunction and neurological damage, treatable by daily injections with cofactor precursor, CPMP [26].

Because redox molybdoenzymes (such as steroid C25 dehydrogenase (S25DH) [27], ethylbenzene dehydrogenase (EBDH) [1], nitrate reductase (NarGH) [28], and dimethyl sulfoxide (DMSO) reductase [29] require cofactor insertion in the cytoplasm, they can only be transported through the membrane in a folded form [30]. A Moco insertion step into an apo-enzyme is assisted by a chaperone protein. Almost all molybdoenzymes have a private chaperone protein that binds Moco and inserts it into the target apo-enzyme [31]. Subsequently, molybdoenzyme can be transported through 
membranes through a TAT-pathway which allows for translocation of fully folded proteins across biological membranes [32]; TAT-pathway substrates possess a characteristic $\mathrm{N}$-terminal amino acid sequence motif that is recognized by a protein from TAT-pathway system [33]. Our focus of this work revolved around a D1 chaperone protein that is considered responsible for loading a maturated form of Moco to the a subunit of S25DH from Sterolibacterium denitrificans (Chol-1ST, DSMZ 13999T) [34] and for transport regulation of folded S25DH enzyme across the membrane via the TAT-pathway [27].

S25DH catalyzes the oxygen-independent hydroxylation of the tertiary C25 carbon atom of the aliphatic side chain of cholesterol and other sterol compounds and sterol derivatives (e.g. calciferol) [13, 35] to the respective tertiary alcohol [27]. S25DH is a heterotrimer with $\alpha \beta \gamma$ composition that belongs to the DMSO reductase family. The $\alpha$ subunit contains bis-MGD and an iron-sulfur cluster, the $\beta$ subunit contains four iron sulfur clusters, and the $\gamma$ subunit a heme $b$ [27]. S25DH can be used as a catalyst in industrial production of calcifediol, which is used in the treatment of vitamin D3 deficiency or rickets $[13,36]$, or 25-hydroxycholesterol, which is an important regulator of immune function [37, 38]. Apart from industrial applications, an efficient overexpression system could expedite research regarding the reaction mechanism of hydroxylation of tertiary carbon atoms by structural experiments combined with computational studies (Rugor et al., to be published).

E. coli is a prokaryotic model organism that plays an important role in industrial microbiology, biotechnology and genetic engineering, both in research and application [39]. It is a facultative anaerobe whose metabolism can change in the presence or absence of oxygen. Under aerobic conditions, E. coli uses $\mathrm{O}_{2}$ as a terminal electron acceptor, while it grows anaerobically by fermentation or respiration [40]. When E. coli respires under anaerobic conditions, it can use acceptors such as nitrate, dimethyl sulfoxide (DMSO), trimethylamine-N-oxide (TMAO), or fumarate [41]. The presence of an electron acceptor induces the expression of a specific reductase: for example, TMAO reductase is expressed in the presence of TMAO, and DMSO and fumarate reductases are expressed when sulfoxides or fumarate are present, respectively [42]. On the molecular level, an FNR (fumarate-nitrate reduction regulator) [43] transcription regulator is responsible for the switch between aerobic and anaerobic respiration in E. coli. Under anaerobic conditions, the FNR monomer acquires the $[4 \mathrm{Fe}-4 \mathrm{~S}]^{2+}$ cluster, and the protein dimerizes and binds to the promotor regions of target genes, leading to the activation of genes whose products function in anaerobic energy metabolism [44-46]. The presence of $\mathrm{O}_{2}$ leads to the decomposition of the $[4 \mathrm{Fe}-4 \mathrm{~S}]^{2+}$ cluster and FNR dimer by monomer dissociation [47] and subsequent repression of expression of genes involved in anaerobic respiration.

E. coli is an organism widely used for the overproduction of recombinant proteins. One of the main obstacles in S25DH heterologous overexpression may be an efficient molybdenum cofactor production by $E$. coli. Although successful overexpression under anaerobic conditions of recombinant molybdoenzyme such as nitrate reductase A (NarGHI) [48] or DmsABC $[41,49,50]$ has been reported, it is unclear whether the $E$. coli Moco loading machinery is compatible with recombinant $S$. denitrificans proteins.

For proteins overexpressed under aerobic conditions, E. coli can be cultured on either rich, minimal, defined, or undefined media [51,52] depending on the need of further experiments. When recombinant protein production is carried out under anaerobic conditions in E. coli, an electron acceptor is added to the growth medium to allow for anaerobic respiration. Under anaerobic conditions the presence of nitrate guarantees the overexpression of nitrate reductase [53]. Addition of DMSO or 
fumarate to the culture medium ensures that $E$. coli use these compounds as terminal electron acceptors for growth.

Apart from studies on the biochemistry of molybdoenzymes, chaperone proteins involved in their maturation such as NarJ [54], DmsD [55] or TorD [56] from E. coli have been also studied. So far, little is known about the D1 chaperone responsible for S25DH maturation or cofactor loading. Here, we present our efforts to optimize both the production of the Moco in E. coli during the overexpression of D1 protein and the yield of the D1 chaperone in both Moco-containing and Moco-free forms. The presented protocols were suitable for further analysis of the protein by extended X-ray absorption fine structure (EXAFS), high performance liquid chromatography (HPLC) and thermofluor shift assays. 


\section{MATERIALS AND METHODS}

\section{Genetic construct preparation}

Using the StarGate ${ }^{\circledR}$ system (IBA GmbH, Göttingen, Germany), the D1 gene (GeneBank: JQ292999.1) of S25DH was cloned into the PASG-IBA5 and PASG-IBA35 vectors according to the protocol provided by the manufacturer. The initial pEntry vector with the D1 gene was obtained from a laboratory stock (the D1 gene was cloned from $S$. denitrificans genomic DNA). The resulting plasmids are referred to as PASG-IBA5+D1 and PASG-IBA35+D1. To prepare expression vectors using the MCSG system [57], the gene coding for D1 was amplified using the following oligonucleotides: D1_For: TACTTCCAATCCAATGCCATGCAAATGAGCAATGCAAACAATACGG, and D1_Rev: TTATCCACTTCCAATGTTAATGTGGCGTGCCGGCCTTCTGC, and cloned into the pMCSG7 vector using protocol described in [57]. Oligonucleotides for PCR reactions were synthesized by Genomed, Warsaw, Poland. The resulting plasmid is referred to as PMCSG7+D1. Schematic diagrams of vectors used in this study are presented in Supplemental Fig. S1.

\section{Bacterial strains}

During the course of the study two E. coli strains, DH5 $\alpha$ (\#18265017, LifeTechnologies) and BL21(DE3)RILP (\#230280, Agilent Technologies) were used. These strains were tested for efficient

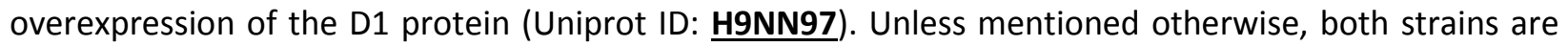
collectively referred to as "E. coli" in the following subsections.

\section{Selecting the vector type (pASG-IBA5 vs pASG-IBA35)}

E. coli cells harboring pASG-IBA5+D1 or pASG-IBA35+ D1 plasmids were grown aerobically in 50 $\mathrm{mL}$ of Luria-Bertani (LB) medium with ampicillin (\#K029.4, Carl Roth) at a final concentration of 100 $\mu \mathrm{g} / \mathrm{mL}$ overnight at $37^{\circ} \mathrm{C}$. For anaerobic cultures, $400 \mathrm{~mL}$ of LB or M9ZB media were prepared in a 500 $\mathrm{mL}$ bottle. The bottle was closed with a rubber stopper, degassed with $\mathrm{N}_{2}$, and autoclaved. The overnight aerobic culture was transferred to the medium through a syringe, without opening the bottle. Cells were cultured at $37^{\circ} \mathrm{C}$ in a presence of ampicillin $(100 \mu \mathrm{g} / \mathrm{mL})$ with shaking until they reached an $\mathrm{OD}_{600}$ of 0.8 . 15 mins before induction, the culture was supplemented with $\mathrm{Na}_{2} \mathrm{MoO}_{4}$ at a final concentration of $10 \mathrm{mM}$. Protein production was induced by addition of anhydrotetracycline (AHT) (\#37919, Sigma-Aldrich) to a final concentration of $0.2 \mu \mathrm{g} / \mathrm{mL}$ ). Overexpression was carried out at $18^{\circ} \mathrm{C}$ overnight or 2 hours at $37^{\circ} \mathrm{C}$. To test the aerobic conditions, the overnight aerobic culture was transferred to $200 \mathrm{~mL} \mathrm{LB}$ medium containing ampicillin $(100 \mu \mathrm{g} / \mathrm{mL})$. 15 minutes before AHT induction the culture was supplemented with $\mathrm{Na}_{2} \mathrm{MoO}_{4}$ as for anaerobic conditions.

\section{Investigation of growth conditions and medium type}

E. coli cells harboring PASG-IBA35+D1 plasmid were grown aerobically in $50 \mathrm{~mL}$ of LB medium overnight at $37^{\circ} \mathrm{C}$. The overnight bacterial culture was transferred to LB or M9ZB medium. In all conditions tested $100 \mu \mathrm{g} / \mathrm{mL}$ ampicillin (\#K029.4, Carl Roth) was used for antibiotic selection.

To test the LB medium and aerobic conditions, cells from the $50 \mathrm{~mL}$ starter culture were transferred to $200 \mathrm{~mL}$ of $\mathrm{LB}$, grown at $37^{\circ} \mathrm{C}$ with shaking until the culture reached an $\mathrm{OD}_{600}$ of 0.8 , and subsequently induced with $0.2 \mu \mathrm{g} / \mathrm{mL}$ anhydrotetracycline (AHT) (\#37919, Sigma-Aldrich). 15 mins before induction with the AHT, the culture was supplemented with $\mathrm{Na}_{2} \mathrm{MoO}_{4}$. After induction, the 
culture grew for 2 hours at $37^{\circ} \mathrm{C}$ and then cells were pelleted. The pellet was stored at $-80^{\circ} \mathrm{C}$ for a few days before purification.

For anaerobic cultures, the $400 \mathrm{~mL}$ of LB or M9ZB media were prepared in a $500 \mathrm{~mL}$ bottle closed with a rubber stopper, degassed with $\mathrm{N}_{2}$ and sterilized by autoclaving. The overnight aerobic culture was transferred to the medium through a syringe, without opening the bottle. In the case when M9ZB medium was tested, cells were grown at $37^{\circ} \mathrm{C}$ with shaking, and induced with AHT $(0.2 \mu \mathrm{g} / \mathrm{mL}$ final) when the culture reached an $\mathrm{OD}_{600}$ of 0.8 . When cells grew anaerobically in LB medium, they were induced at an $\mathrm{OD}_{600}$ of $0.5 . \mathrm{Na}_{2} \mathrm{MoO}_{4}(10 \mathrm{mM}$ final concentration) was supplemented 15 minutes before induction with AHT $\left(0.2 \mu \mathrm{g} / \mathrm{mL}\right.$ final). The culture was grown for 2 hours at $37^{\circ} \mathrm{C}$ and then cells were pelleted. The pellet was stored at $-80^{\circ} \mathrm{C}$ for a few days before purification.

\section{Aerobic expression: pMCSG7+D1 in BL21(DE3)RILP cells}

For expression under aerobic conditions BL21(DE3)RILP cells harboring the pMCSG7 plasmid comprising the D1 gene were grown in $50 \mathrm{ml}$ of Lennox LB medium (\#LBL405, BioShop Canada Inc.) with $100 \mu \mathrm{g} / \mathrm{mL}$ ampicillin (\#K029.4, Carl Roth) and $34 \mu \mathrm{g} / \mathrm{mL}$ chloramphenicol (\#227920250, Acros Organics) overnight at $37^{\circ} \mathrm{C}$ with shaking. The next day the culture was transferred to $4 \mathrm{~L}$ of Terrific-Broth (TB) medium (\#TER409, BioShop Canada Inc.) with ampicillin and chloramphenicol for selection, and cells were grown at $37^{\circ} \mathrm{C}$ until the culture reached an $\mathrm{OD}_{600}$ of 1.2 . The temperature was decreased to $18^{\circ} \mathrm{C}$ and cells were induced with $0.15 \mathrm{mM}$ isopropyl $\beta$-D-1-thiogalactopyranoside (IPTG) (\#CN08.3, Carl Roth). Protein production took place overnight at $18^{\circ} \mathrm{C}$. Cells were centrifuged and the pellet was stored at -80 ${ }^{\circ} \mathrm{C}$ for a few days before purification.

\section{Purification of D1 protein expressed from pASG-IBA5 vector in DH5 $\alpha$ cells under anaerobic conditions}

Protein purification was carried out under $\mathrm{N}_{2}$ atmosphere $\left(\mathrm{N}_{2} / \mathrm{H}_{2}\right.$ filled glovebox, Coy Laboratory Products). Cell pellets were suspended in $10 \mathrm{~mL}$ of lysis buffer containing $100 \mathrm{mM}$ Tris- $\mathrm{HCl} \mathrm{pH} \mathrm{8.0,150}$ $\mathrm{mM} \mathrm{NaCl}$, DNase (\#10104159001, Roche), lysozyme (\#8259.2, Roth) and protease inhibitor (cOmplete, EDTA-free Protease Inhibitor Cocktail Tablets, Roche). Cells were sonicated for 3 minutes with 3 seconds on and 5 seconds off, and the lysate was clarified by centrifugation for 40 minutes at 40000 rcf. Lysates were applied to $0.5 \mathrm{~mL}$ of Strep-Tactin ${ }^{\circledR}$ Sepharose $^{\circledR}$ resin (\#2-1201-010, IBA GmbH) equilibrated with lysis buffer. Resin with bound protein was washed with $5 \mathrm{~mL}$ of the lysis buffer. Protein was eluted with a $100 \mathrm{mM}$ Tris- $\mathrm{HCl} \mathrm{pH} \mathrm{8.0,150} \mathrm{mM} \mathrm{NaCl}$ and $2.5 \mathrm{mM}$ desthiobiotin (\#2-1000-002, IBA GmbH) buffer.

\section{Purification of D1 protein expressed from pASG-IBA35 vector in DH5 $\alpha$ cells under anaerobic conditions (D1 $\left.1_{\text {anaerobic }}\right)$}

Protein purification was carried out under $\mathrm{N}_{2}$ atmosphere $\left(\mathrm{N}_{2} / \mathrm{H}_{2}\right.$ filled glovebox, Coy Laboratory Products). Cell pellets were suspended in $10 \mathrm{~mL}$ of lysis buffer containing $2 \mathrm{mM}$ imidazole, $50 \mathrm{mM}$ Tris$\mathrm{HCl} \mathrm{pH} \mathrm{7.7,} 150 \mathrm{mM} \mathrm{NaCl}$, DNase (\#10104159001, Roche), lysozyme (\#8259.2, Roth) and protease inhibitors (cOmplete, EDTA-free Protease Inhibitor Cocktail Tablets, Roche). Cells were sonicated for 3 minutes with 3 seconds on and 5 seconds off, and the lysate was clarified by centrifugation for 40 minutes at 40000 rcf. The lysate was applied to $750 \mu \mathrm{L}$ NiNTA (\#2-3206-010, IBA GmbH) resin equilibrated with lysis buffer. Resin with bound protein was washed with $5 \mathrm{~mL}$ of buffer containing 10

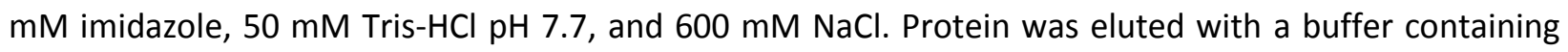
$250 \mathrm{mM}$ imidazole, $50 \mathrm{mM}$ Tris- $\mathrm{HCl}$ pH 7.7, and $150 \mathrm{mM} \mathrm{NaCl}$. D1 ${ }_{\text {anaerobic }}$ was concentrated on Amicon ${ }^{\circledR}$ 
Ultra filters (\#UFC901024, Millipore) with a $10 \mathrm{kDa}$ cut-off to a final concentration of $14 \mathrm{mg} / \mathrm{mL}$, as measured by a Bradford assay.

\section{Purification of D1 protein expressed from pMCSG7 vector in BL21(DE3)RILP cells under aerobic conditions} (D1 $\left.1_{\text {aerobic }}\right)$

For aerobic protein purification, the cell pellet was suspended in $100 \mathrm{~mL}$ of a lysis buffer composed of $2 \mathrm{mM}$ imidazole, $50 \mathrm{mM}$ Tris- $\mathrm{HCl}$ pH 7.7, $150 \mathrm{mM} \mathrm{NaCl}$, DNase (\#10104159001, Roche), lysozyme (\#8259.2, Roth) and protease inhibitors (cOmplete, EDTA-free Protease Inhibitor Cocktail Tablets, Roche). Cells were sonicated for 10 minutes with 3 seconds on and 5 seconds off, and the lysate was clarified by centrifugation for 40 minutes at 40000 rcf. The lysate was applied to $3 \mathrm{~mL}$ of NiNTA (\#23206-010, IBA GmbH). Resin with bound protein was washed with $5 \mathrm{~mL}$ of buffer containing $10 \mathrm{mM}$ imidazole, $50 \mathrm{mM}$ Tris- $\mathrm{HCl} \mathrm{pH} \mathrm{7.7,} \mathrm{and} 600 \mathrm{mM} \mathrm{NaCl}$. Protein was eluted with a buffer containing 250 $\mathrm{mM}$ imidazole, $50 \mathrm{mM}$ Tris- $\mathrm{HCl} \mathrm{pH} \mathrm{7.7,} \mathrm{and} 150 \mathrm{mM} \mathrm{NaCl}$. The $\mathrm{N}$-terminal 6xHis-tag was removed by recombinant 6xHis-tagged Tabacco Etch Virus (rTEV). Proteolytic cleavage was carried out overnight at $4^{\circ} \mathrm{C}$ during dialysis in $1 \mathrm{~L}$ of a digestion buffer containing $50 \mathrm{mM}$ Tris- $\mathrm{HCl} 7.9,150 \mathrm{mM} \mathrm{NaCl}$ and $\beta$ mercaptoethanol. To remove rTEV protease, cleaved tag, and uncut protein the dialyzed protein was loaded onto $3 \mathrm{~mL}$ of NiNTA resin previously equilibrated with the digestion buffer. Flow through was collected, concentrated using Amicon ${ }^{\circledR}$ Ultra filters (\#UFC901024, Millipore) with a $10 \mathrm{kDa}$ cut-off, and loaded onto a size exclusion Superdex 200 column equilibrated with digestion buffer (without $\beta$ mercaptoethanol) attached to AKTA FPLC purification system (GE Healthcare Life Sciences). Fractions containing D1 protein were pooled together and concentrated on Amicon ${ }^{\circledR}$ Ultra filters with a $10 \mathrm{kDa}$ cut-off to $14 \mathrm{mg} / \mathrm{mL}$ or $18 \mathrm{mg} / \mathrm{mL}$, as measured by absorbance at $280 \mathrm{~nm}$ using a Biotek Epoch plate reader.

\section{Analysis of molybdenum content}

Inductively coupled plasma mass spectrometry (ICP-MS) analyses were carried out using an ELAN 6100 mass spectrometer (Perkin Elmer). According to the certification the molybdenum detection level was in a range between $0.3 \mathrm{nM}$ and $10 \mu \mathrm{M}$. A buffer, in which analyzed protein was stored, was used as a blank. Molybdenum content in each protein sample was compared to its content in the buffer control. The final volume of each sample was $5 \mathrm{~mL}$ and the protein concentration used for analysis was $10 \mu \mathrm{M}$.

\section{Crystallization trials}

Crystallization of D1 protein was performed under both aerobic and anaerobic conditions. For anaerobic conditions, crystallization trials for D1 were set in a glove box using the following crystallization screens: Index (\#HR2-144) and SaltRx (\#HR2-107 and \#HR2-109) from Hampton Research. For aerobic trials crystallization of D1 was set up using the following screens: Peg lon (\#HR-2-139) and Crystal Screen (\#HR2-133) from Hampton Research, TOP96 (\#TOP96-10ML), MCSG1 (\#MCSG1-4T), MCSG2 (\#MCSG2-4T), MCSG3 (\#MCSG3-4T), and MCSG4 (\#MCSG4-4T) from Anatrace. In case of D1 $1_{\text {aerobic }}$ protein, different concentrations of protein were tested: $6 \mathrm{mg} / \mathrm{mL}, 8 \mathrm{mg} / \mathrm{mL}, 10 \mathrm{mg} / \mathrm{mL}, 12 \mathrm{mg} / \mathrm{mL}$, and $18 \mathrm{mg} / \mathrm{mL}$. Under anaerobic conditions, a crystallization drop was constituted by mixing protein with a crystallization buffer in a glovebox as a sitting drop. Under aerobic conditions, drops were set as a sitting drop against $1.5 \mathrm{M} \mathrm{NaCl}$ using $0.2 \mu \mathrm{L}$ of commercially available crystallization screens and $0.2 \mu \mathrm{L}$ of 
protein using Mosquito (TTP Labtech). Optimization of crystallization conditions that gave positive hits in aerobic conditions was done using Optimatrix Maker (Rigaku). Crystallization experiments of D $1_{\text {aerobic }}$ in complex with guanine and/or ammonium molybdate, and streptomycin were also set. Preliminary diffraction data were collected using SuperNova diffractometer (Rigaku Oxford Diffraction) equipped with microfocus CuK $\alpha$ (1.54 A) and CCD Atlas detector. Data was indexed using HKL3000 [58].

\section{Thermofluor shift assay (TSA)}

A thermofluor shift assay was used to screen for conditions (such as buffering compound or the presence of ligands) that may stabilize or destabilize a protein [59]. Initial concentrations of D1 aerobic and D1 $1_{\text {anaerobic }}$ protein, and SYPRO Orange label (\#S6651, LifeTechnologies) were checked in a test run. The assay was carried out in a 96-well plate (Hard-Shell PCR Plates \# HSP9601, BioRad) in a CFX Connect (buffer screening) or CFX 96 (ligand screening) Real-Time PCR (BioRad). The total reaction volume was $25 \mu \mathrm{L}$. D1 protein in $50 \mathrm{mM}$ Tris- $\mathrm{HCl} \mathrm{pH} 7.5$ and $150 \mathrm{mM} \mathrm{NaCl}$ was tested at 4 concentrations: 0.5 $\mathrm{mg} / \mathrm{mL}, 1 \mathrm{mg} / \mathrm{mL}, 2 \mathrm{mg} / \mathrm{mL}$, and $4 \mathrm{mg} / \mathrm{mL}$. SYPRO Orange concentration was tested at dilutions 1:5000 and 1:2500 of the $5000 x$ concentrated stock solution prepared in $50 \mathrm{mM} \mathrm{Tris-HCl} \mathrm{pH} 7.5$ and $150 \mathrm{mM}$ $\mathrm{NaCl}$.

Buffers and ligand screening were done following a similar protocol as for protein concentration tests with a few exceptions. $2.5 \mu \mathrm{L}$ of $\mathrm{D} 1_{\text {aerobic }}$ at $18 \mathrm{mg} / \mathrm{mL}$ in $50 \mathrm{mM}$ Tris- $\mathrm{HCl} \mathrm{pH} 7.5$ and $150 \mathrm{mM} \mathrm{NaCl}$ buffer was mixed with $1 \mu \mathrm{L}$ of the working stock solution of SYPRO Orange. The SYPRO Orange working stock solution was prepared by $100 x$ dilution of the $5000 x$ concentrated stock solution in $50 \mathrm{mM} \mathrm{Tris-HCl}$ pH 7.5 and $150 \mathrm{mM} \mathrm{NaCl}$. For buffer screening, the solution of respective buffer was added to the sample to the final volume of $25 \mu \mathrm{L}$. The compositions of buffers are presented in Table 1 . For ligand screening, $5 \mu \mathrm{L}$ of the ligand was added to the sample followed by addition of $50 \mathrm{mM}$ Tris- $\mathrm{HCl} \mathrm{pH} 7.5$ to a final volume of $25 \mu \mathrm{L}$. The list of ligands is presented in Table 2. All solutions of ligands were prepared in water. Protein, buffers and ligands were added to wells in a 96-well plate (Hard-Shell PCR Plates, BioRad) with a multichannel pipette. The 96-well plates were sealed with Optical Sealing Tape (BioRad, \#2239444) and centrifuged at $200 \mathrm{rpm}$ for 2 minutes. Unfolding curves were generated using a temperature gradient from $20^{\circ} \mathrm{C}$ to $95^{\circ} \mathrm{C}$ with a heating rate of $1^{\circ} \mathrm{C} / \mathrm{min}$. Melting temperature values $\left(T_{m}\right.$ values) were determined from the maximum of the first derivative of the raw data.

\section{Size exclusion chromatography (SEC FPLC)}

Size exclusion chromatography (SEC) analysis was carried out on an AKTA FPLC purification system using a Superdex200 column (GE Healthcare) equilibrated with a buffer composed of $50 \mathrm{mM}$ Tris- $\mathrm{HCl} 7.8$ and $150 \mathrm{mM} \mathrm{NaCl}$. Two samples of D1 protein were used, one with $10 \mathrm{mM}$ of dithiothreitol (DTT) and the other without reducing agent. 15 nmoles of each sample of D1 $1_{\text {aerobic }}$ protein were injected onto the column. 0.1 umoles of guanosine diphosphate (GDP) were added to the sample to check possible binding to $\mathrm{D} 1_{\text {aerobic }}$. Protein molecular mass was evaluated based on a calibration curve prepared using the following protein standards: ferritin - $440 \mathrm{kDa}$, conalbumin - $75 \mathrm{kDa}$, carbonic anhydrase - $29 \mathrm{kDa}$, and ribonuclease $13.7 \mathrm{kDa}$. Standards were purchased from GE Healthcare Life Sciences. 


\section{Size exclusion chromatography (SEC HPLC)}

HPLC analysis were carried out on Agilent 1100 VL LC/MSD using Yarra SEC-2000 column (Phenomenex). The column was equilibrated with $6 \mathrm{M}$ guanidine- $\mathrm{HCl}$ and $50 \mathrm{mM}$ sodium phosphate $\mathrm{pH}$ 6.5. $20 \mu \mathrm{L}$ of the $\mathrm{D} 1_{\text {anaerobic }}$ protein was transferred into a glass vial under anaerobic atmosphere and 20 $\mu \mathrm{L}$ of buffer composed of $8 \mathrm{M}$ guanidine- $\mathrm{HCl}$ and $50 \mathrm{mM}$ sodium phosphate $\mathrm{pH} 6.5$ was added to the protein. $20 \mu \mathrm{L}$ of $\mathrm{D} 1_{\text {aerobic }}$ protein was mixed with $20 \mu \mathrm{L}$ of the same buffer under aerobic conditions. A reducing agent (DTT) was added where indicated into protein samples. Mobile phase did not contain DTT. $10 \mu \mathrm{L}$ samples were injected into the column. Protein molecular mass was evaluated based on calibration curve prepared using following protein standards: conalbumin - $75 \mathrm{kDa}$, ovoalbumin -44 $\mathrm{kDa}$, and ribonuclease 13.7 kDa. Standards were purchased from GE Healthcare Life Sciences.

\section{X-ray Absorption Spectroscopy}

X-ray absorption spectroscopy (XAS) was carried out as previously described in detail [60]. Samples for XAS were loaded into $2 \times 10 \times 10 \mathrm{~mm}$ acrylic sample cuvettes within an anaerobic glove box and frozen using a liquid nitrogen-cooled cold block. XAS data were acquired at the Stanford Synchrotron Radiation Lightsource (SSRL) with the SPEAR storage ring containing $500 \mathrm{~mA}$ at $3.0 \mathrm{GeV}$. Data were collected using the structural molecular biology XAS 7-3 and 9-3, both of which are equipped with $\mathrm{Si}(220)$ double crystal monochromators, and Rh coated mirrors, with the mirror set so that critical angle corresponds to about $23 \mathrm{keV}$ in order to reject harmonics. The use of an upstream vertically collimating mirror combines excellent monochromator energy resolution and energy stability. Incident and transmitted $\mathrm{X}$-ray intensities were monitored using nitrogen-filled ionization chambers using a sweeping voltage of $1.8 \mathrm{kV}$ to ensure the linear response of the ionization chambers, and X-ray absorption was measured as the Mo $\mathrm{K} \alpha$ fluorescence excitation spectrum using an array of 30 germanium detectors [61] together with zirconium filters and a Soller slit assembly to preferentially reject scattered radiation so as to maintain the detector count rate in the pseudo-linear regime. Highspeed analog detector readout electronics were used with a Gaussian shaping time of $0.125 \mu \mathrm{s}$. Samples were maintained at a temperature of approximately $10 \mathrm{~K}$ during data collection using an Oxford instruments liquid helium flow cryostat. For each data set, between eight and fourteen scans each of 40 minutes duration were accumulated, and the energy was calibrated by reference to the absorption of a molybdenum foil measured simultaneously with each scan, assuming a lowest energy inflection point of $20003.9 \mathrm{eV}$. The energy threshold of the extended X-ray absorption fine structure (EXAFS) oscillations ( $k$ $=0 \AA^{-1}$ ) was assumed to be $20025.0 \mathrm{eV}$.

\section{XAS data analysis}

The EXAFS oscillations $\chi(k)$ were quantitatively analyzed by curve-fitting using the EXAFSPAK suite of computer programs [http://ssrl.slac.stanford.edu/exafspak.html] as previously described [62], using ab initio theoretical phase and amplitude functions calculated using the program FEFF version 8.25 [63]. No smoothing, filtering or related operations were performed on the data. 


\section{RESULTS}

The D1 chaperone is a link between E. coli-synthesized Moco and recombinant overexpressed $\mathrm{S} 25 \mathrm{DH}$. The first goal of this project was to optimize growth conditions for efficient production of the Moco-loaded D1 chaperone which, in effect, would allow for protocols suitable for production of active recombinant S25DH. The second goal was to develop a method for obtaining a high amount of soluble protein for biophysical and biochemical studies. The developed methods should allow for selective production Moco-loaded and Moco-free D1 protein - a feature that would streamline further studies on the mechanism of Moco loading by the molybdenum enzyme chaperones.

\section{Optimization of the genetic construct and purification strategy}

Optimization of purification methods was first conducted, and affinity purification systems based on His-tag and Strep-tag were compared. Under aerobic and anaerobic growth conditions, we tested two vectors: pASG-IBA5, which harbors an N-terminal Strep-tag, and pASG-IBA35, which harbors an $\mathrm{N}$-terminal $6 x \mathrm{His}$-tag. In all cases, $\mathrm{DH} 5 \alpha$ cells were used. Expression and purification utilizing pASGIBA35+D1 and immobilized $\mathrm{Ni}^{2+}$ metal affinity chromatography $\left(\mathrm{Ni}^{2+} \mathrm{IMAC}\right)$ were found to be superior to protocols using the PASG-IBA5+D1 vector: a) in anaerobic conditions, the yield of purified D1 protein was 20x higher for pASG-IBA35+D1 than for PASG-IBA5+D1 (4.25 mg compared to $0.2 \mathrm{mg}$ of purified protein per $1 \mathrm{~L}$ of M9ZB medium), b) in aerobic conditions, protein yield was 12x higher when pASGIBA35+D1 vector was used (12 mg compared to $0.9 \mathrm{mg}$ of protein of purified protein per $1 \mathrm{~L}$ of LB medium).

\section{Optimization of the bacterial strain and medium composition}

To select the most optimal E. coli strain and growth conditions, we used pASG-IBA35+D1 vector and aerobic $\mathrm{Ni}^{2+}$ IMAC purification. UV-VIS measurements were carried out immediately after the final purification step (elution from column).

We compared the performance of two strains of E. coli - BL21(DE3)RILP and DH5 $\alpha$, which originate from different ancestors ( $B$ and K12 strain, respectively) and show differences in some metabolic pathways [64]. We tested both aerobic and anaerobic conditions and media types and analyzed cell growth rate, yield of purified protein, and Moco retention in a protein. Proteins containing Moco with molybdenum atom have been reported to exhibit a signature absorption peak in the visible range $\sim 450 \mathrm{~nm}$ [65] that is lost during the oxidation of Moco and loss of molybdenum thiolate ligands. The exact absorption peak wavelength depends on the environment of the Moco. For D $1_{\text {anaerobic, }}$ we have observed a characteristic peak at $410 \mathrm{~nm}$. During the process of protein production optimization, we have monitored the absorbance at $410 \mathrm{~nm}$ as well as the presence of molybdenum by ICP-MS to confirm Moco retention. The list of tested conditions and analysis results are briefly described here and summarized in Supplemental Table 1.

DH5 $\alpha$ cells cultured under aerobic conditions in LB medium ( $\left.\mathrm{DH} 5 \alpha_{\text {aerobic }}\right)$ reached an $\mathrm{OD}_{600}$ of 0.6 within 3 hours after inoculation and were then induced with AHT. The yield of the purified protein was 5 $\mathrm{mg}$ of D1 from a $400 \mathrm{~mL}$ culture (Supplemental Fig. S2B), but the protein did not show absorbance at $410 \mathrm{~nm}$ and did not contain the molybdenum. When DH5 $\alpha$ cells grew under anaerobic conditions in LB medium ( $\left.\mathrm{DH} 5 \alpha_{\text {anaerobic-LB }}\right)$, the culture grew slowly and cells reached $\mathrm{OD}_{600}$ of 0.5 after several hours, but they did not grow any further. The yield of purified protein was $0.2 \mathrm{mg}$ from a $400 \mathrm{~mL}$ culture 
(Supplemental Fig. S2B) and there was no detected absorbance at $410 \mathrm{~nm}$. The low amount of the protein did not allow for ICP-MS analysis. When $\mathrm{DH} 5 \alpha$ cells grew under anaerobic conditions using M9ZB minimal medium ( $\mathrm{DH} 5 \alpha_{\text {anaerobic-м9zв }}$ ) supplemented with $\mathrm{NaNO}_{3}$, the culture reached an $\mathrm{OD}_{600}$ of 0.6 within 4 hours, purified protein absorbed at $410 \mathrm{~nm}$, and molybdenum was detected by ICP-MS. The purification yield was comparable to yields from aerobic cultures (3.4 mg from a $400 \mathrm{~mL}$ culture) (Supplemental Fig. S2A).

BL21(DE3)RILP cells grew well under aerobic conditions in LB medium, the yield of purified protein $\left(4.8 \mathrm{mg} / 400 \mathrm{~mL}\right.$ ) was comparable to yield from DH5 $\alpha_{\text {aerobic }}$ (Supplemental Fig. S3B), and the purified protein did not absorb at $410 \mathrm{~nm}$. Similarly, poor growth was observed for BL21(DE3)RILP cells that grew using $\mathrm{NaNO}_{3}$ as the sole source of electron acceptors in respiratory chain. The cultures did not grow beyond an $\mathrm{OD}_{600}$ of 0.2 ; therefore, $\mathrm{D} 1$ overexpression levels were not tested. We have tested an alternate electron acceptor, fumarate, as a negative control. The yield of D1 protein purified from RILP cells that grew using M9ZB medium supplemented with fumarate was $1.2 \mathrm{mg}$ from a $400 \mathrm{~mL}$ culture (Supplemental Fig. S3A), but the overexpressed protein did not absorb at $410 \mathrm{~nm}$ even if $\mathrm{NaNO}_{3}$ was added just before protein induction with AHT. The molybdenum levels for all samples from BL21(DE3)RILP were below detection limit of ICP-MS. There was not enough protein to test samples from BL21(DE3)RILP cultured anaerobically in the presence of $\mathrm{NaNO}_{3}$ in $\mathrm{M9ZB}$ or LB media (Supplemental Table 1).

We concluded that modified M9ZB medium, anaerobic conditions and DH5 $\alpha$ cells are suitable for production of D1 protein, showing UV-VIS features of Moco and molybdenum retention. Since there

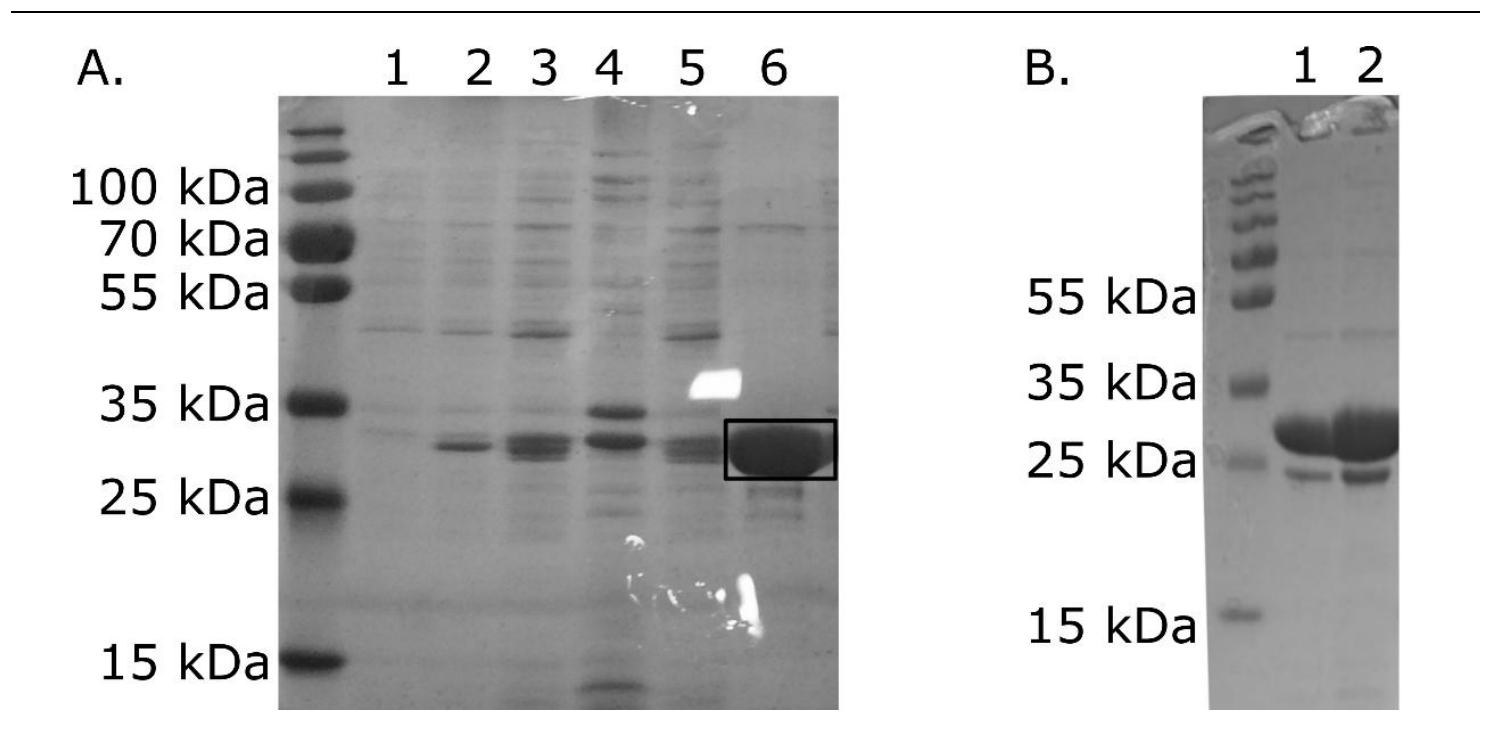

Figure 1. D $1_{\text {anaerobic }}$ protein purity. Protein was expressed in $\mathrm{DH} 5 \alpha$ from the pASG-IBA35 vector A. Steps of $D 1_{\text {anaerobic }}$ purification process. Numbers above the gel mark fractions: 1 - before induction, 2- after induction, 3 - lysate, 4- pellet after centrifugation at 40000 rcf, 5- NiNTA flow through, 6 - elution (this D $1_{\text {anaerobic }}$ protein batch was used for EXAFS experiments). The marked band with mass $30 \mathrm{kDa}$ corresponds to $\mathrm{D} 1$ protein. $\mathrm{B}$. The purity of $\mathrm{D} 1_{\text {anaerobic }}$ protein batch used for TSA, crystallization and SEC HPLC analysis (lanes 1 and 2). 
was no significant difference in the amount of protein produced when D1 was overexpressed over-night at $18^{\circ} \mathrm{C}$ or for 2 hours at $37^{\circ} \mathrm{C}$, we decided to follow the 2 hours' protocol in the later experiments.

Finally, the purification protocol was optimized to be carried out under anaerobic conditions and resulted in a yield $5 \mathrm{mg}$ of pure D1 protein from $400 \mathrm{~mL}$ M9ZB medium (Fig. $1 \mathrm{AB}$ ). For further discussion, we will refer to the protein purified according to this protocol as $D 1_{\text {anaerobic. The protein was }}$ concentrated to $14 \mathrm{mg} / \mathrm{mL}$ and subjected to size exclusion chromatography (SEC) HPLC-DAD analysis and extended X-ray absorption fine structure (EXAFS) experiments to verify the presence of Moco. Further analysis showed that protein expressed under aerobic conditions in BL21(DE3)RILP was free of Moco (Fig. 2A).

\section{Size exclusion chromatography with diode array detector (SEC HPLC-DAD).}

We used SEC HPLC analysis to check whether the D1 anaerobic protein contains Moco. An anaerobically purified native $\mathrm{S} 25 \mathrm{DH}$ enzyme [27] was used as a positive control, while D1 $1_{\text {aerobic }}$ served as a negative control. Chromatograms of all samples confirmed the presence of proteins (peaks 1, 2, and 3 Fig. 2A). The detected peak 4 in $D 1_{\text {anaerobic }}$ and $\mathrm{S} 25 \mathrm{DH}$ samples corresponds to a small molecule, as deduced from its retention time (Fig. 2A). The small molecular compound (peak 4) was eluted separately from the $D 1_{\text {anaerobic }}$ only in the presence of DTT, suggesting the presence of a disulfide bond between this compound and the protein. The absorbance spectra of the compounds present in the S25DH sample and separated from the $\mathrm{D} 1_{\text {anaerobic }}$ sample overlapped with each other (Fig. $2 \mathrm{~B}$ ). This compound was not detected in the $D 1_{\text {aerobic }}$ sample. $D 1_{\text {anaerobic }}$ and $D 1_{\text {aerobic }}$ proteins exist as monomers ( $\left.30 \mathrm{kDa}\right)$, with a small portion of dimeric fraction ( $60 \mathrm{kDa}$ ). When DTT was present, only the monomeric form of D1 was detected (Fig. 2A).

\section{X-ray Absorption Spectroscopy}

A comparison of the Mo K-edge X-ray absorption near-edge spectra with those of selected Mo
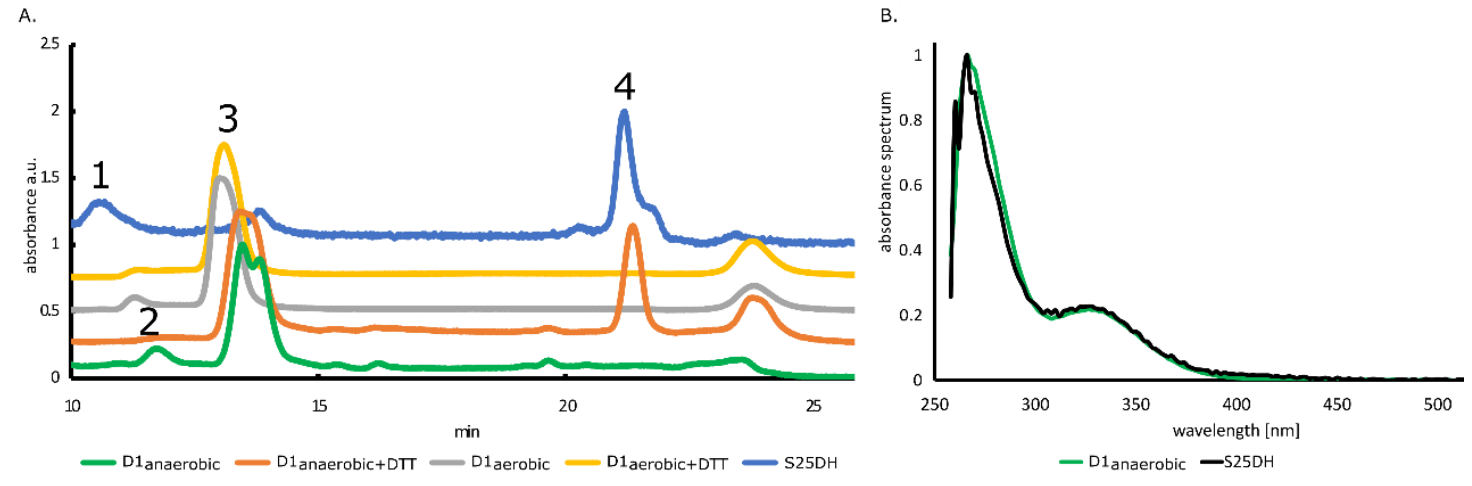

Figure 2. SEC HPLC-DAD analysis of $D 1_{\text {anaerobic, }} D 1_{\text {aerobic }}$ and S25DH proteins. A. HPLC elution profile of D1 $1_{\text {anaerobic }}$ (green - without DTT, orange - with DTT), D1 aerobic (grey - without DTT, yellow - with DTT) and S25DH (blue). For D1 $1_{\text {aerobic }}$ (green line) three peaks were detected with masses corresponding to $29 \mathrm{kDa}$ and $32 \mathrm{kDa}$ referred as monomeric fractions (peak 3), and 59 $\mathrm{kDa}$ - referred as dimer (peak 2). For $\mathrm{D} 1_{\text {anaerobic }}$ (grey line) two peaks were detected, dimer (peak 2) and monomer (peak 3). In samples with DTT, there was only single peak (peak 3 ) detected with a mass corresponding to $32 \mathrm{kDa}$ ( $D 1_{\text {anaerobic }}$ ) or $35 \mathrm{kDa}$ ( $\mathrm{D} 1_{\text {aerobic }}$ ). B. Absorption spectra of compounds released from analyzed proteins (peak 4). 
enzymes shows clearly distinct near-edge spectra, as shown in Fig. 3. The enzymes for which spectra are shown were selected to represent the diverse coordination environments of molybdenum enzyme systems, a wider range of near-edge spectra are compared in George, G.N., 2017 [60]. Ordinary Mo Kedge XAS spectra have substantial broadening due to the short core-hole lifetime of the Mo 1s level, but nevertheless a careful comparison of features can be informative. One characteristic feature of Mo enzyme near-edge spectra is the $1 \mathrm{~s} \rightarrow 4 \mathrm{~d}$ "oxo-edge" feature observed in the K-edge spectra of some enzymes. This is best seen for the cis-dioxo $\mathrm{Mo}(\mathrm{VI})$ site of sulfite oxidase in Figure 3D. This feature is a formally dipole-forbidden $\Delta l=+2$ transition but which gains dipole-allowed $\Delta l=+1$ intensity through admixture of p-orbitals through ligand $\pi$-bonding [66]. The absence of this feature in the spectrum of the D1 chaperone suggests the absence of $\mathrm{Mo}=\mathrm{O}$ bonds (Fig. 3). The EXAFS, together with the best fits, are shown in Fig. 4. The EXAFS shows a clear beat around $k=8 \AA^{-1}$ with two peaks clearly observed in the Fourier transform (Fig. 4B). In agreement with the near-edge spectra, no low- $R$ peak at $\sim 1.7 \AA$ characteristic of $\mathrm{Mo}=\mathrm{O}$ backscattering is observed in the Fourier transform. The transform peaks are primarily typical of Mo-S backscattering at $\sim 2.3 \AA$ with a substantial presence of Mo $\cdots$.Metal backscattering giving rise to the pronounced transform peak at $\sim 2.7 \AA$. The EXAFS curve-fitting analysis $[60,67]$ indicates that the EXAFS fits best to three Mo-S at $2.32 \AA$, with one or two long Mo-O at 2.20 $\AA$. The longer-range metal backscattering fits well to two $\mathrm{Mo} \cdots \mathrm{Fe}$, Ni or $\mathrm{Cu}$ at $2.72 \AA$, clearly indicating the unexpected presence of a multi-metallic cluster. 


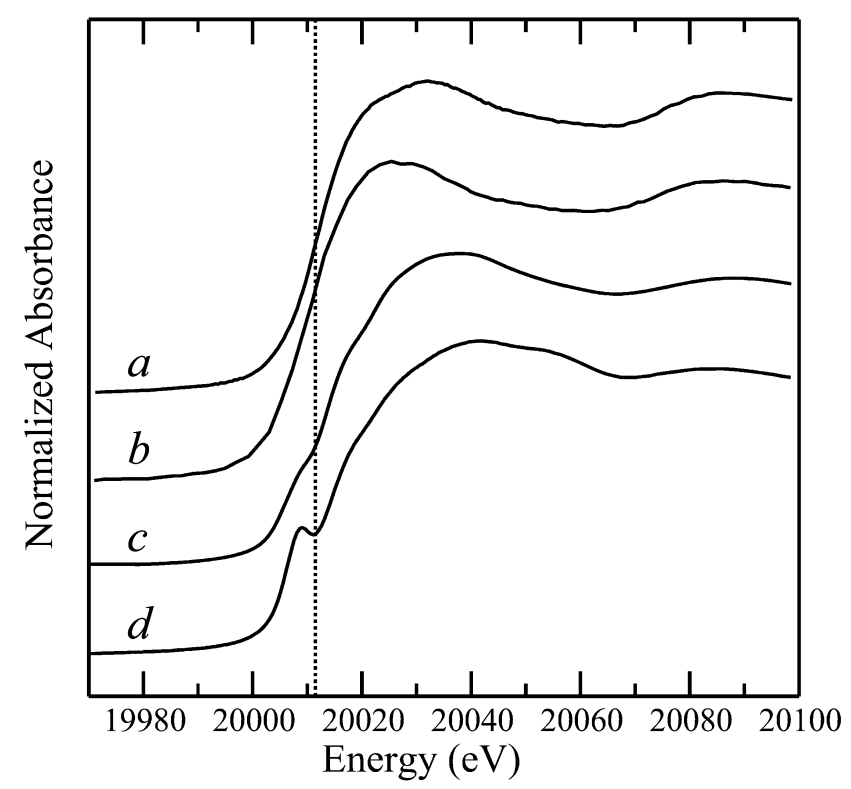

Figure 3. Comparison of Mo K-edge X-ray absorption near-edge spectra of D1 the chaperone (a) with Klebsiella pneumoneii nitrogenase MoFe protein (b), oxidized Rhodobacter sphaeroides DMSO reductase (c) and oxidized human sulfite oxidase (d). The vertical broken line is included to guide the eye to relative shifts of the spectra.

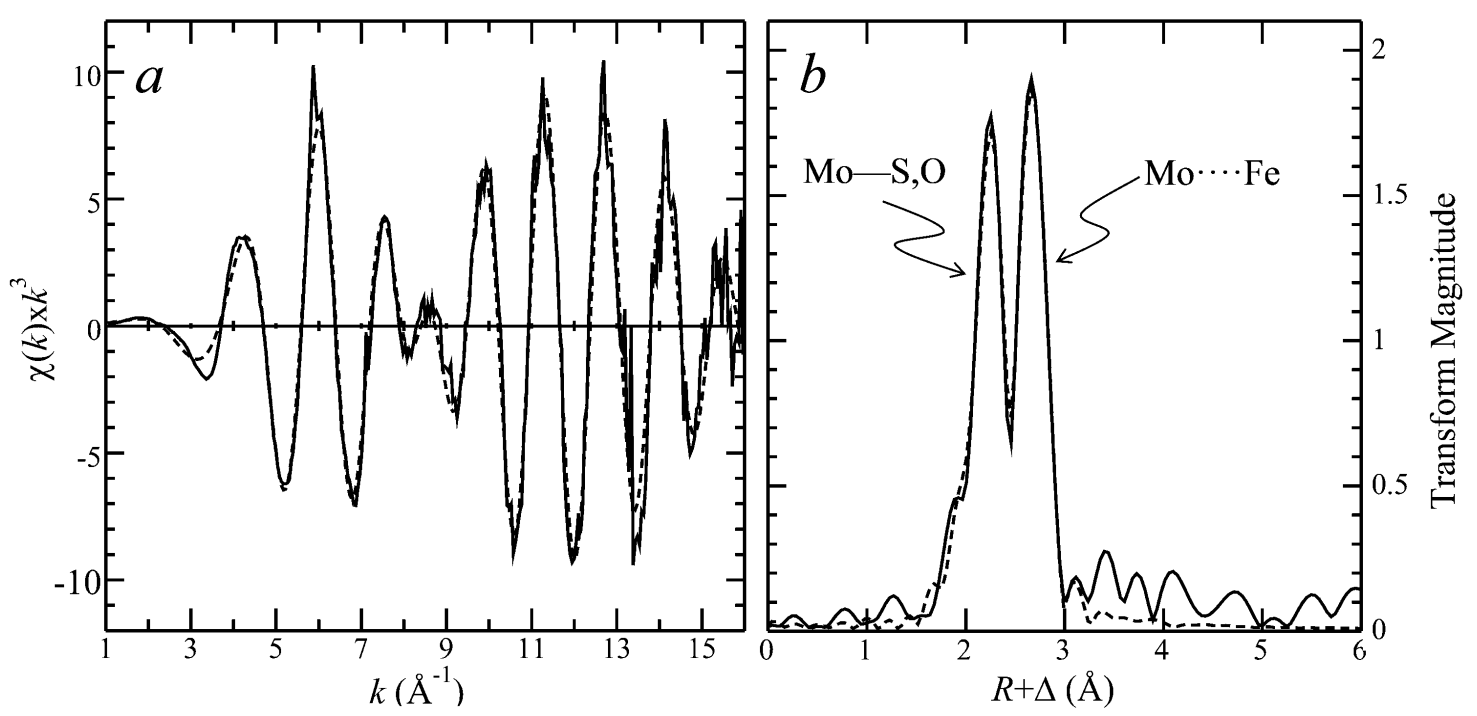

Figure 4. D1 chaperone Mo K-edge EXAFS (solid line) and best fit (broken line) (a) together with the corresponding EXAFS Fourier transforms (phase corrected for Mo-S backscattering) (b). EXAFS curve-fitting gives best fits with a mixed $\mathrm{Mo}-\mathrm{S} / \mathrm{Mo}-\mathrm{O}$ first shell coordination with $3 \mathrm{Mo}-\mathrm{S}$ at 2.321(3) $\AA\left(\sigma^{2}=0.0044(5) \AA^{2}\right)$ and $2 \mathrm{Mo}-\mathrm{O}$ at $2.21(5) \AA\left(\sigma^{2}=0.0031(7) \AA^{2}\right)$ with 2 Mo …Fe at 2.727(2) $\left(\sigma^{2}=0.0016(3) \AA^{2}\right)$. We note that $2 \mathrm{Mo} \cdots \mathrm{Cu}$ at $2.717(2)\left(\sigma^{2}=0.0025(1) \AA^{2}\right)$ gave an essentially equivalent fit but with a more chemically reasonable value for $\sigma^{2}$. 


\section{Characterization of $\mathrm{D} 1_{\text {aerobic }}$ - size exclusion chromatography and GDP binding}

Having confirmed that D1 protein expressed in a B strain derivative in aerobic conditions does not contain Moco, we decided to use this strain for production of the protein without the cofactor for further analysis. We decided to use a vector with a cleavable N-terminal His-tag, the pMCSG7 vector. BL21(DE3)RILP cells reached an $\mathrm{OD}_{600}$ of 0.87 hours after inoculation, and the yield of purified protein was $16 \mathrm{mg}$ from $1 \mathrm{~L}$ of TB (Fig. 5).

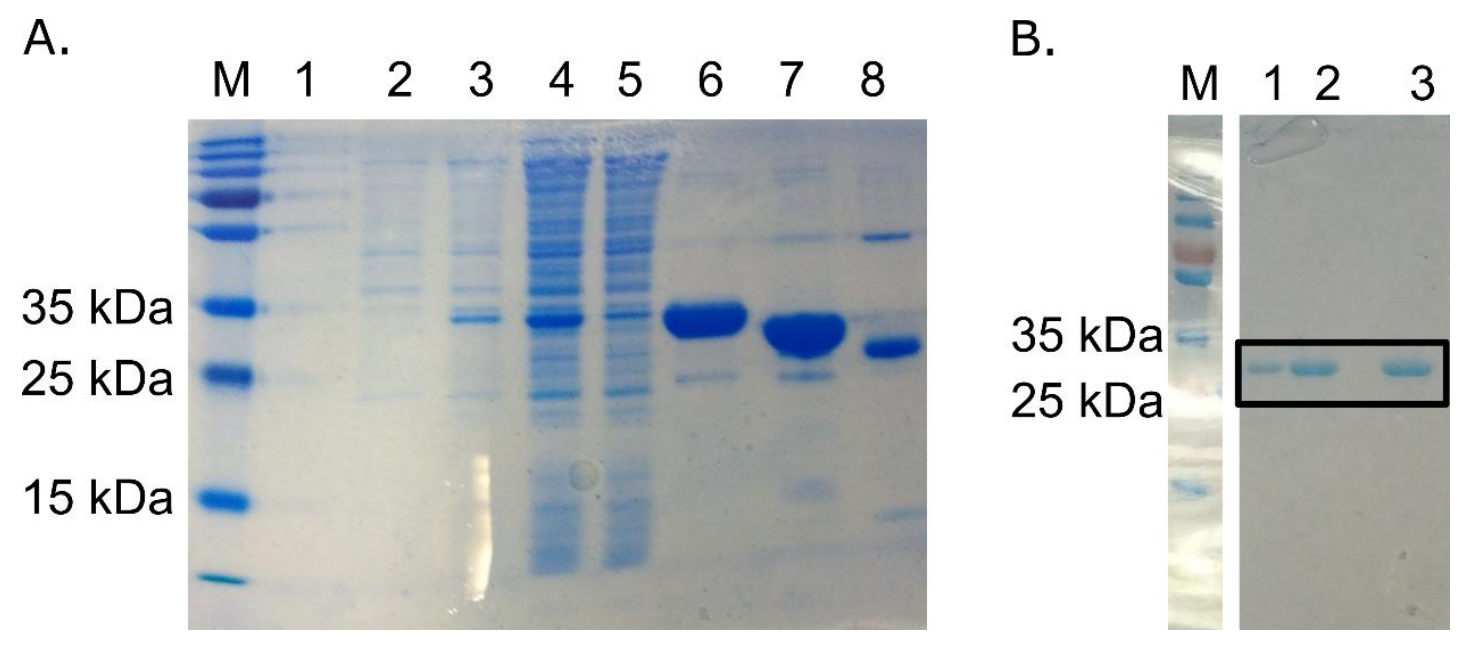

Figure 5. D1 $1_{\text {aerobic }}$ protein purity. Protein was expressed in BL21(DE3)RILP from pMCSG7+D1 vector. A. Steps of $D 1_{\text {aerobic }}$ purification process. Numbers above the gel mark fractions: $1-$ before induction, 2- after induction, 3 - lysate, 4- pellet after centrifugation at $40000 \mathrm{rcf}, 5$ NiNTA flow through, 6 - elution, 7 - D $1_{\text {aerobic }}$ digested with rTEV, 8-rTEV sample. B. The purity of $D 1_{\text {aerobic }}$ protein after SEC FPLC. This protein batch was used for TSA, ITC, crystallization and SEC FPLC analysis (lanes 1, 2 and 3).

After prolonged exposure of $\mathrm{D} 1_{\text {aerobic }}$ protein to atmospheric air (oxygen), stable oligomeric conglomerates were shown, as verified by SEC. This change in protein oligomerization state was completely reversible upon addition of a reducing agent (DTT) (Fig. 6), thereby supporting the assumption regarding the presence of protein surface cysteines that are prone to oxidation and formation of intermolecular disulfide bridges. SEC fast protein liquid chromatography (FPLC) elution profiles of $D 1_{\text {aerobic }}$ protein incubated with DTT indicate the apparent mass of D $1_{\text {aerobic }}$ as being between monomer and dimer ( $45 \mathrm{kDa}$ ), while the apparent mass of protein without addition of DTT was between dimer and tetramer (110 kDa) (Fig. 6). 


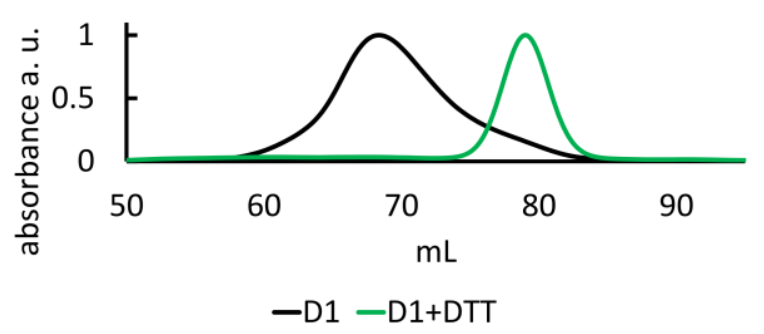

Figure 6. SEC FPLC elution profile of $D 1_{\text {aerobic }}$ protein. A. Oligomerization of $D 1_{\text {aerobic }}$ after incubation in aerobic atmosphere. D1 $1_{\text {aerobic }}$ forms oligomers in size of app. $110 \mathrm{kDa}$ (black line) upon prolonged exposure to atmospheric oxygen. This process is reversible after addition of reducing agent (green line), the apparent size of $\mathrm{D} 1_{\text {aerobic }}$ protein is $45 \mathrm{kDa}$ ). Normalized data of absorbance at $280 \mathrm{~nm}$ are presented.

SEC HPLC analysis of $\mathrm{D} 1_{\text {aerobic }}$ protein revealed that it does not contain a ligand that could potentially be co-purified with recombinant $\mathrm{D} 1_{\text {aerobic }}$ protein (Fig. $2 \mathrm{~A}$ ). Therefore, $\mathrm{D} 1_{\text {aerobic }}$ samples could be used for binding experiments to check the possible interaction with molecules resembling bis-MGD (Moco type) fragments, such as guanosine diphosphate (GDP). The analysis of an available crystal structures of a sulfurtransferase, a chaperone protein for a formate dehydrogenase with bound guanosine diphosphate (GDP) (PDB ID: 4PDE) [68], and biochemical studies on a DmsD chaperone protein $[69,70]$ suggested that the GDP or GTP can be used to detect interactions between a chaperone and guanosine nucleotide moiety of MGD (Moco type). Therefore, we used GDP as an MGD surrogate and we checked whether D1 $1_{\text {aerobic }}$ interacts with GDP by thermofluor shift assay (TSA), SEC FPLC and isothermal titration calorimetry (ITC). There was no significant change in protein stability when TSA measurements were performed using different concentrations of GDP, suggesting a lack of GDP binding to $\mathrm{D} 1_{\text {aerobic }}$. Recorded melting temperatures for various GDP concentrations were less than $3^{\circ} \mathrm{C}$ between each condition, with no correlation between $\mathrm{dT}_{\mathrm{m}}$ and GDP concentration (Fig. 7A). The lack of interactions between the D1 protein and GDP was additionally confirmed by SEC FPLC (Fig. 7B) and ITC (Fig. 7C). The absorption peak of GDP is $254 \mathrm{~nm}$, but it also absorbs at $280 \mathrm{~nm}$, so the absorption of the complex of GDP and D1 protein should have a slightly higher absorbance measured at $280 \mathrm{~nm}$ than that of a protein alone. After addition of an excess of GDP, we observed the unbound GDP in late eluting fractions and did not observe a change in absorbance of the D1 aerobic sample (Fig 7B). ITC analysis showed that the addition of GDP to the $\mathrm{D} 1_{\text {aerobic }}$ protein did not generate heat attributable to the binding (Fig. 7C). 


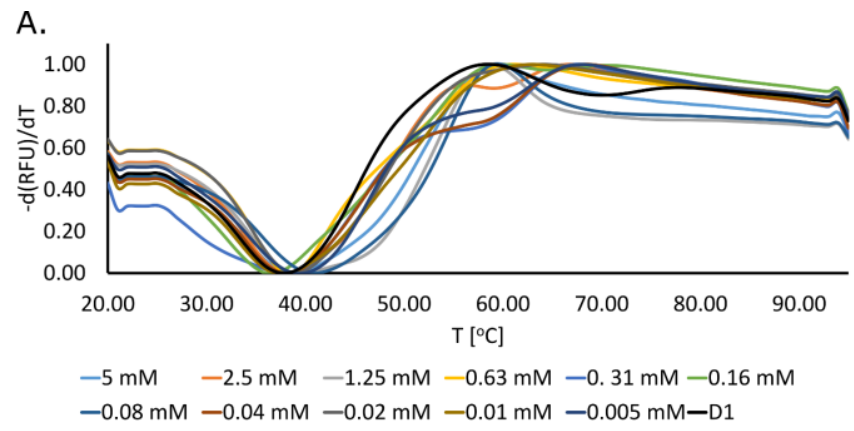

B.
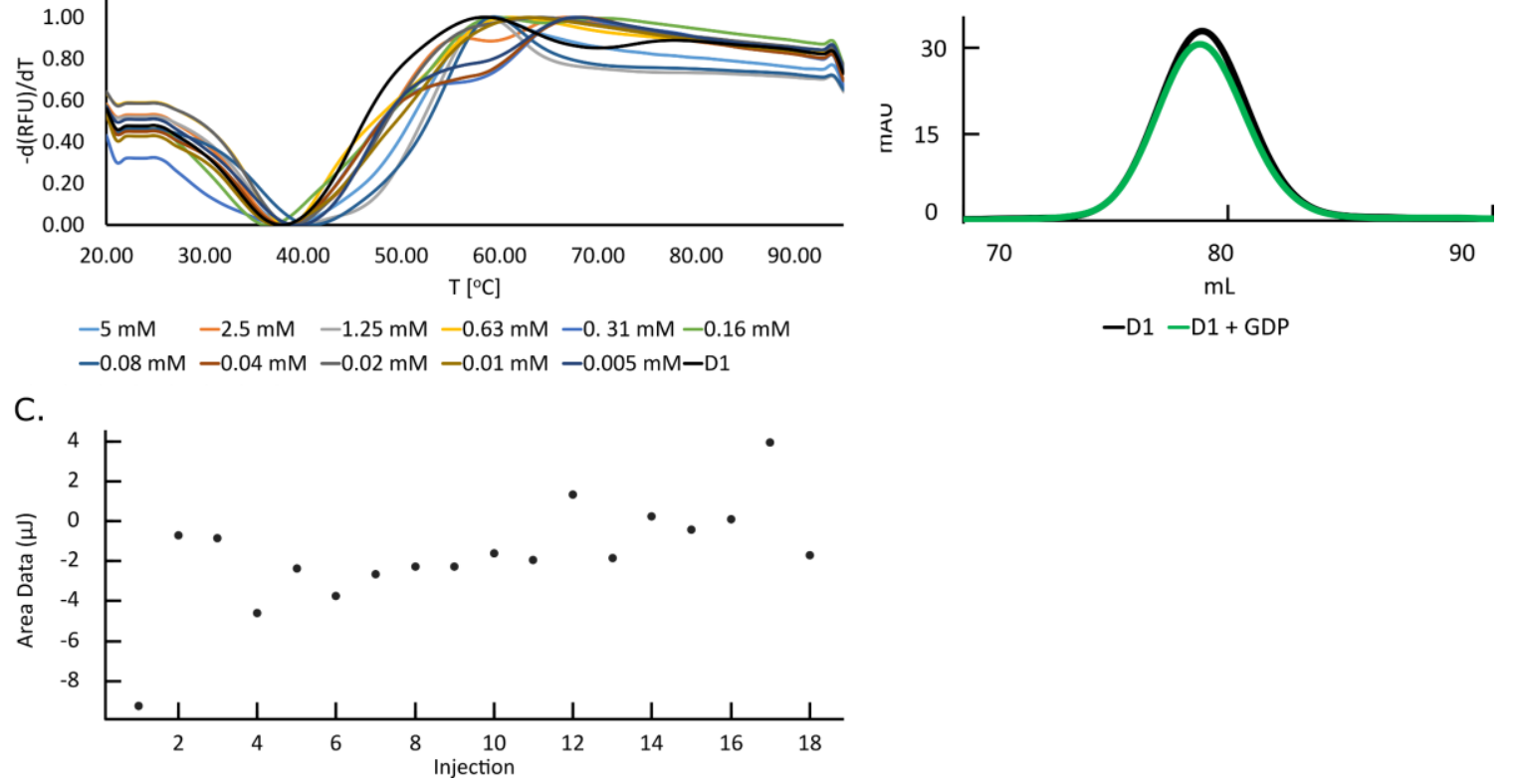

Figure 7. No interaction between chaperone D1 and GDP was detected by thermofluor shift assay (TSA), size exclusion chromatography and isothermal titration calorimetry (ITC). A. Data from TSA experiments show that the stability of $D 1_{\text {aerobic }}$ is not affected by GDP. TSA was performed in a presence of decreasing GDP concentrations. $T_{m}$ of $D 1_{\text {aerobic }}$ equaled $38^{\circ} \mathrm{C}$. The recorded change of $D 1_{\text {aerobic }}$ stability in the presence of GDP was less than $3{ }^{\circ} \mathrm{C}$ for each condition. B. Data from size exclusion chromatography. The absorbance at $280 \mathrm{~nm}$ of $\mathrm{D} 1_{\text {aerobic }}$ protein did not change when GDP was added to the sample indicating that GDP does not interact with a protein. C. Data from ITC experiments of D $1_{\text {aerobic }}$ with GDP. The plot presents integrated heat values of each injection. The blank values were subtracted from heat values generated after titration of GDP to $\mathrm{D} 1_{\text {aerobic }}$. No interaction between $\mathrm{D} 1_{\text {aerobic }}$ and GDP was detected by ITC.

\section{Stability tests and ligand screening by thermofluor shift assay (TSA)}

We checked the influence of Moco presence on protein stability and assessed how conditions such as $\mathrm{pH}$ and the presence of ligands affected the melting temperature $\left(\mathrm{T}_{\mathrm{m}}\right)$ of D1. The stability of $\mathrm{D} 1_{\text {aerobic }}$ and $\mathrm{D} 1_{\text {anaerobic }}$ proteins was analyzed in a series of buffers (Table 1 ) based on triple component buffer systems [71] developed for optimization of protein crystallization. We measured the stability of proteins within the $\mathrm{pH}$ range 6.0-8.0. The $\mathrm{D} 1$ protein was most stable at $\mathrm{pH} \geq 7.0$, both for anaerobic and aerobic samples. One exception was recorded for buffer \#1, in which protein was most stable at pH of 6.0 and 6.5. In some buffers (aerobic \#2, \#4, \#6, Fig. 8 and Table 1) there was a main single transition recorded with a $\mathrm{T}_{\mathrm{m}}$ around $40^{\circ} \mathrm{C}$, while for the buffer \#1 (aerobic), there were at least two main transitions recorded, suggesting two main unfolding (melting) events occurring during sample denaturation.

The interpretation of the melting curves of the anaerobic samples was not straightforward. Although there was one main transition, the plotted peak $(-d(R F U) / d T)$ was broader than for aerobic 
samples and its shape suggested that there were several unfolding events occurring at the similar temperature. Overall, both $\mathrm{D} 1_{\text {aerobic }}$ and $\mathrm{D} 1_{\text {anaerobic }}$ proteins were more stable at higher $\mathrm{pH}$ values, and $\mathrm{pH}$ values below 6.5 were detrimental for protein stability (maximum observed $\mathrm{dT}$ of $17^{\circ} \mathrm{C}$ when the $\mathrm{pH}$ changes from pH 6.0 to 8.0 for anaerobic buffer \#5). D1 $1_{\text {aerobic }}$ was slightly more stable at lower pH values (pH 6.0) than $\mathrm{D} 1_{\text {anaerobic }}$ while $\mathrm{D} 1_{\text {anaerobic }}$ preferred higher $\mathrm{pH}$ (7.5-8.0) than $\mathrm{D} 1_{\text {aerobic }}$ (7.0-7.5).

We also tested the stability of $D 1_{\text {anaerobic }}$ after overnight exposure to the atmospheric oxygen (Fig. 8). The exposed samples were measured in the same set of buffers covering the $\mathrm{pH}$ range between 6.0 and 8.0 (Table 1). The most significant decrease in $\mathrm{D} 1_{\text {anaerobic }}$ stability was observed for buffer \#4 at $\mathrm{pH} 7.5\left(\mathrm{dT}-3^{\circ} \mathrm{C}\right)$, while the most significant increase was observed for buffer $\# 6$ at $\mathrm{pH} 6.0\left(\mathrm{dT} 4^{\circ} \mathrm{C}\right)$. These differences are similar to those between buffers used for measuring D1 $1_{\text {aerobic. }}$ stability.

In addition to identifying conditions that improve D1 stability, we determined whether particular compounds that may bind to D1 in the absence of Moco, and, in turn, stabilize or destabilize D1 protein. We designed a 96-well plate with compounds of various chemical composition such as nucleotides, purine-based compounds, sugars, antibiotics, metal ions, and amino acids (Table 2). Sugars, purine based ligands, and nucleotides did not affect protein stability; virtually no change in protein melting temperature was observed (less than $\mathrm{dT}=3^{\circ} \mathrm{C}$ ). In the presence of aromatic amino acids ( $\operatorname{Trp}$, Tyr and Phe), there was no transition observed for $D 1_{\text {aerobic }}$. Other tested amino acids did not change
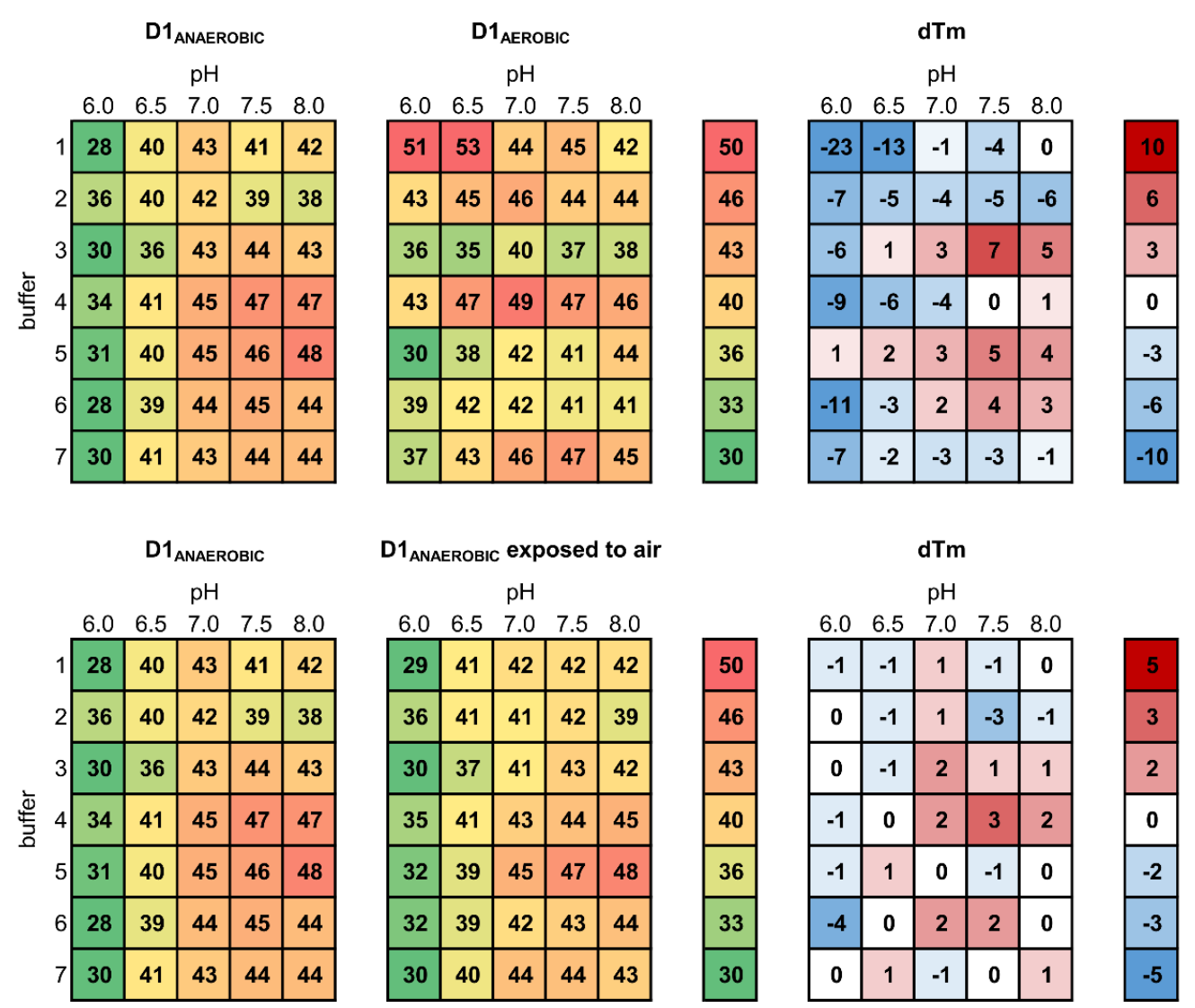

D1 $1_{\text {ANAEROBIC }}$ exposed to air
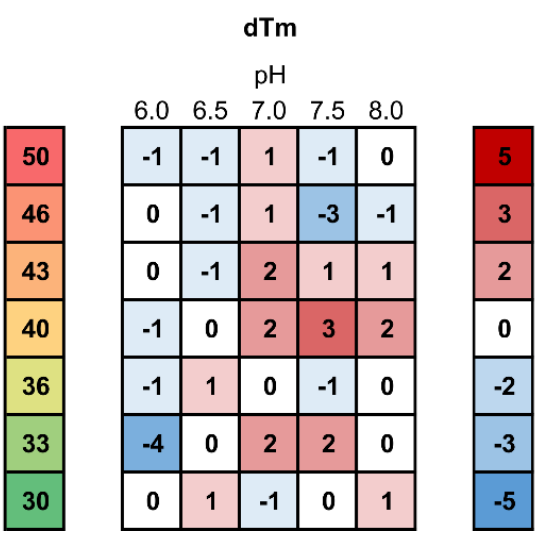

Figure 8. Stability of $D 1_{\text {aerobic }}$ and $D 1_{\text {anaerobic }}$ measured by TSA. The numbers from 1-7 correspond to different buffers which compositions are presented in Table 1 . The numbers above each chart correspond to $\mathrm{pH}$ value of a given buffer. Green and orange plots represent recorded $T_{m}$ values, while red and blue plots the $d T_{m}=T_{m}\left(D 1_{\text {anaerobic }}\right)-T_{m}\left(D 1_{\text {aerobic. }}\right)$ (top) or $d T_{m}=T_{m}\left(D 1_{\text {anaerobic }}\right)-T_{m}\left(D 1_{\text {anaerobic }}\right.$ exposed to air.) (bottom). Color scale for each type of plot is presented next to the plot. 
protein stability ( $\mathrm{dT}$ less than $3^{\circ} \mathrm{C}$ ). We observed a significant increase of $\mathrm{D} 1_{\text {aerobic }}$ stability in the presence of zinc $\left(\mathrm{dT}=25^{\circ} \mathrm{C}\right)$, nickel $\left(\mathrm{dT}=12^{\circ} \mathrm{C}\right)$, and cadmium $\left(\mathrm{dT}=12^{\circ} \mathrm{C}\right.$ ) ions as well as one aminoglycoside antibiotic, streptomycin ( $\mathrm{dT}=10^{\circ} \mathrm{C}$ ) (Fig. 9 and Supplemental Fig. S4 AB). For two other aminoglycoside antibiotics, apramycin and paromomycin, two transition states were detected with the main denaturation event happening around $40^{\circ} \mathrm{C}$ and the second, less pronounced at $55^{\circ} \mathrm{C}$. We observed $\mathrm{D} 1_{\text {aerobic }}$ destabilization in the presence of ammonium molybdate $\left(\mathrm{dT} 19^{\circ} \mathrm{C}\right.$ ) (Fig. 9). There was no transition observed for $\mathrm{D}_{\text {aerobic }}$ in the presence of $\mathrm{CuCl}_{2}, \mathrm{CoCl}_{2}$, Tris(2-carboxyethyl)phosphine hydrochloride (TCEP), FAD, Hepes, $3.5 \mathrm{M}$ urea, or guanidinium hydrochloride (1 M and $3.5 \mathrm{M}$ ). Supplemental Fig. S5 presents the results of TSA for all measured compounds that had an influence on $T_{m}$ of $D 1_{\text {aerobic }}$.

\section{Crystallization trials}

The quality and amount of purified $\mathrm{D} 1_{\text {anaerobic }}$ and $\mathrm{D} 1_{\text {aerobic }}$ was sufficient for crystallization trials (Fig. 1B and Fig. 5B). The initial screening using commercial sparse screening kits resulted in the following crystallization conditions for $\mathrm{D} 1_{\text {aerobic }}$ that were further improved by grid optimization: (a) 0.2 $\mathrm{M}$ zinc acetate dihydrate, 20\% Peg $3350 \mathrm{pH} 6.4$ (Hampton Research, Peglon, \#C2) and (b) $0.2 \mathrm{M} \mathrm{MgCl}_{2}$ hexahydrate, 30\% PEG 4000, 0.1 M Tris-HCl pH 8.5 (Hampton Research, Crystal Screen, \#A6).

The conditions with magnesium chloride resulted in small crystals $(30 \mu \mathrm{m} \times 30 \mu \mathrm{m})$ diffracting to $9 \AA$ (Supplemental Fig. S6). Indexing of the collected data was consistent with a primitive monoclinic lattice, with unit cell parameters $a=73, b=180, c=113$ and $\beta=102^{\circ}$. Crystals that grew in the presence of zinc ions were too small and fragile for harvesting.

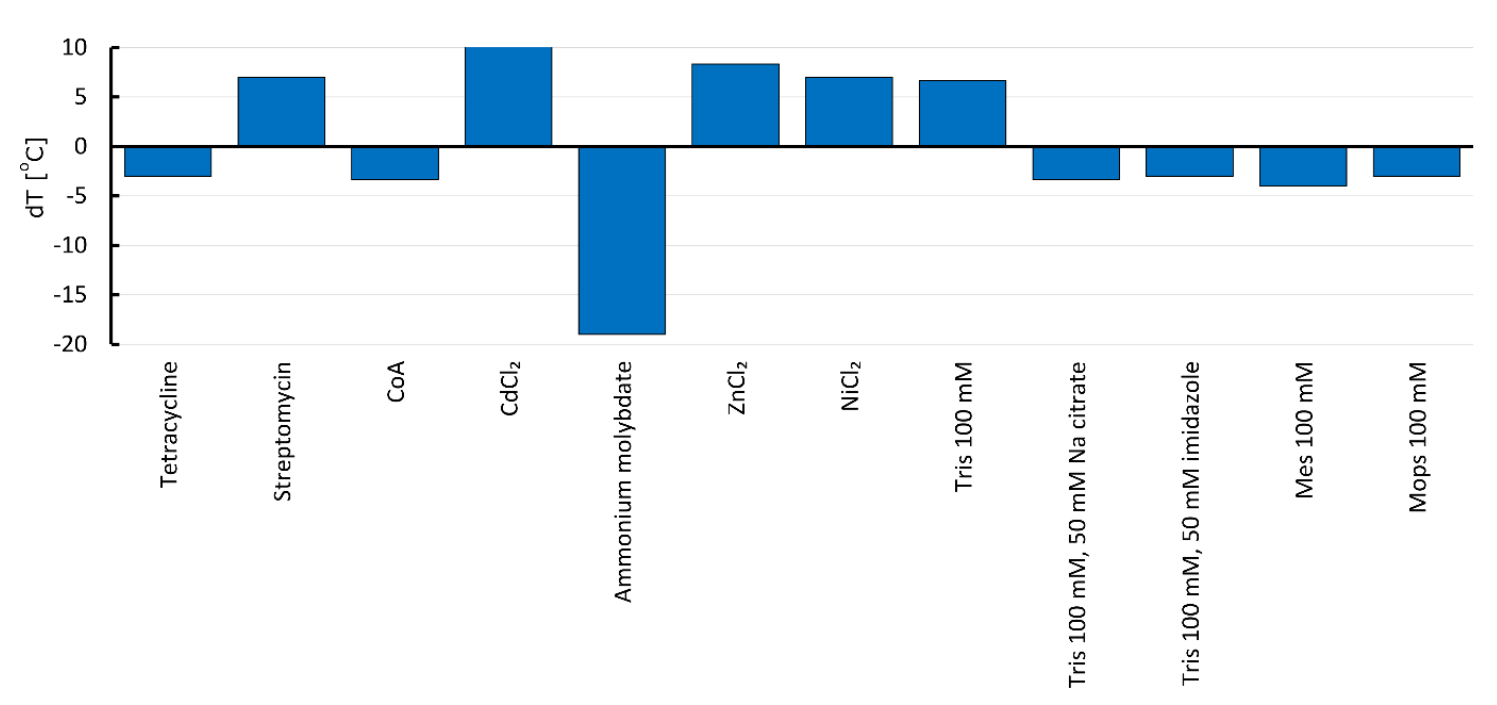

Figure 9. TSA measurements for ligands. Measurements were done in triplicates; an average value is shown. $T_{m}$ for D1 protein equals $40^{\circ} \mathrm{C}$. All tested compounds are listed in Table 2. Compounds for which it was not possible to calculate $T_{m}$ or for which the $d_{m}$ was less than $3^{\circ} \mathrm{C}$ are not presented on the plot. The list of compounds for which $T_{m s}$ were recorded is presented in Supplemental Fig. S5. 


\section{DISCUSSION}

Optimization of recombinant expression of complex biocatalysts, multi-subunit enzymes relying on diverse cofactors is a daunting task. The process of overexpression of such enzymes in an active form is further complicated. For example, when proteins such as S25DH are assembled and loaded with redox cofactor within the cytoplasm, and they must be transported through the membrane in a fully folded form to the dedicated periplasmic space [72], which involves tight regulations by specific chaperones for cofactor insertion [15]. Although the protocol for purification of the steroid C25 dehydrogenase from its natural source has been already established [27] and simplified [35], the successful recombinant expression of the S25DH would have significant impact on production of sterol-based pharmaceutics. To tackle the multi-subunit, multi-cofactors issue we have adopted a "divide-and-conquer" strategy [73] the main goal of obtaining the protein with cofactor was divided into smaller independent steps that were separately solved, altogether leading to the answer of how to get the cofactor-loaded chaperone.

In this work, we report an optimized protocol for production of a D1 chaperone protein involved in maturation of a subunit of S25DH. We have developed protocols for expression and purification of this protein loaded with molybdenum cofactor (Moco) and without Moco depending on the growth conditions, system for protein overexpression and $E$. coli bacterial strain. These two different protocols allow for choosing a method to produce the soluble and pure recombinant chaperone protein suitable for further protein-based studies or applications. The resulting amount of purified protein is sufficient for biochemical and biophysical studies, including procedures in which protein without cofactor may be needed, such as binding assays, antibody production, structural characterization, and protein stability assays.

\section{Determination of the Moco presence in D1 protein}

One of our main goals in this study was to increase D1 yield. Using the 6xHis-tagged construct rather than the Strep-tagged construct resulted in improvement in the amount of produced protein. Doing so may have influenced D1 mRNA performance during protein synthesis or introduced positive changes in protein conformation, thereby diminishing its aggregation. The observed higher yield may have also resulted from a greater binding capacity of NiNTA resin than that of Strep-Tactin. This difference was also noted in manufacturers' manuals. Additionally, because Strep-Tactin is a proteinbased resin it losses its capacity and stability overtime. This decrease is resin performance may also lead to incomplete binding of a protein to the Strep-Tactin (Supplemental Fig. S7) resin that also result in observed lower yield of purified Strep-tagged protein. We did not observe a significant decrease in the performance of resin composed of nitrilotriacetic (NTA) acid, which is a component of NiNTA resins. We used immobilized metal affinity chromatography (IMAC) for D1 purification as the differences in genetic construct and type of purification resin resulted in 20x better protein yield. Contamination of a purified protein sample with E. coli native proteins that nonspecifically interact with NiNTA resin [74, 75] were removed by SEC (Fig. 5B).

Next, we focused on optimization of a protocol for production of D1 protein loaded with Moco. We tested $E$. coli strain, medium type, and culture growth conditions. We checked two $E$. coli strains of different ancestry, $\mathrm{DH} 5 \alpha$ (K12 strain derivative) and BL21(DE3)RILP (B strain derivative). Although DH5 $\alpha$ cells are typically used for plasmid amplification rather than for protein production, $\mathrm{DH} 5 \alpha$ cells produced D1 loaded with Moco when cultured anaerobically on M9ZB minimal media supplemented with 
molybdenum sulfate and $\mathrm{NaNO}_{3}$. Supplementation with $\mathrm{NaNO}_{3}$ under anaerobic conditions was especially crucial because the $\mathrm{NaNO}_{3}$ is a very effective inducer of expression of a molybdoenzyme, nitrate reductase. Because the nitrate reductase production is induced, all metabolic pathways involved in molybdenum cofactor synthesis are active. Therefore, subsequent induction of D1 chaperone protein overexpression by AHT was conducted in an environment satisfying the conditions for cofactor synthesis $[76,77]$.

The BL21(DE3)RILP strain was not able to produce large amounts of the protein loaded with Moco that may be due to described metabolic differences between DH5 $\alpha$ and BL21(DE3)RILP [64]. All descendants of E. coli B type cells lack fnr gene [64]. Fumarate-nitrate regulator (FNR) directly or indirectly regulates, as a transcriptional regulator, the expression of a very large number of genes and operons and controls many aspects of metalloprotein biosynthesis in E. coli [78]. Additionally, due to the lack of the modE gene, BL21 cells also demonstrate impaired molybdenum transport activity [64]. ModE is a molybdenum-responsive transcriptional regulator that acts also as an enhancer of the expression of genes coding for molybdoenzymes, both directly and indirectly [79]. Inefficient Moco production in BL21(DE3)RILP allowed us to develop and optimize protocols for production of Moco-free protein for biochemical or biophysical studies.

Analysis of the $D 1_{\text {anaerobic }}$ sample suggests the presence of the same type of cofactor as in S25DH. The presence of bis-MGD type of Moco in S25DH is predicted based on similarity to other proteins of the DMSO reductase family. SEC HPLC analysis shows that the absorption spectra of cofactors isolated from D1 $1_{\text {anaerobic }}$ and S25DH protein were identical with a comparable retention time (Fig. 2B). EXAFS analysis confirmed the presence of molybdenum and sulfur atoms (Mo-S), environment indicating presence of molybdenum cofactor in $\mathrm{D} 1_{\text {anaerobic }}$ as well. The EXAFS analysis shows that the molybdenum coordinates three sulfurs (Fig. 4). As D1 has only two cysteines and exists in monomeric form, it is likely that at least one dithiolate ligand of Moco is coordinated by the molybdenum atom. The third sulfur may come either from the protein or from a second dithiolate (in the case of bis-MGD type of Moco). Because the cofactor dissociates from $\mathrm{D} 1_{\text {anaerobic }}$ under denaturing conditions only after addition of DTT (Fig. 2B) and mature enzymes from the DMSO reductase family contain bis-MGD, these data may be explained by a model where bis-MGD is covalently attached to $D 1_{\text {anaerobic }}$ by a disulfide bond in our $D 1_{\text {anaerobic }}$ samples. It is unclear whether this covalent attachment is of biological relevance, as the EXAFS results indicated unexpected $\mathrm{Mo} \cdots(\mathrm{Cu}, \mathrm{Ni}, \mathrm{Fe})$ interaction. $\mathrm{D} 1_{\text {anaerobic }}$ could contain nickel ions due to adopted purification strategy, and the presence of $\mathrm{Ni}^{2+}$ may explain the observed EXAFS spectra. The nickel ions may form Mo-Ni-S clusters similar to Mo-Cu-S clusters observed in copper poisoning [80] and possibly affect the interaction between $\mathrm{D} 1_{\text {anaerobic }}$ and bis-MGD. Such Mo-Ni-Cu clusters are known in the small molecule literature [81] and have also been reported in complexes containing Mo bound with a dithiolene ligand [82].

Effectively, we have demonstrated that an anaerobic environment and $\mathrm{NaNO}_{3}$ supplementation are necessary for efficient production of recombinant protein containing Moco and that the $E$. coli produced Moco/MGD can be incorporated into D1 chaperone.

\section{Biochemical characterization of Moco-free D1 chaperone}

The protocols for anaerobic and aerobic expression and purification of D1 were efficient enough to carry on experiments to determine protein stability, oligomerization state, and binding propensity for 
various ligands. When working with protein overproduction many efforts are directed towards optimizing conditions that prevent protein aggregation and degradation.

We determined conditions that stabilize the protein. Although, in general the protein was most stable at $\mathrm{pH}$ higher than 7.0 and $\mathrm{D} 1_{\text {anaerobic }}$ preferred $\mathrm{pH}$ higher than $\mathrm{D} 1_{\text {aerobic, }} \mathrm{D} 1_{\text {aerobic }}$ was most stable buffer \#1 at pH 6.0 and 6.5, suggesting that the interactions between buffer components and $\mathrm{D} 1_{\text {aerobic }}$ either changed the $\mathrm{pH}$ stability profile of the protein or the protein-buffer component complex was formed at a lower $\mathrm{pH}$ (Fig. 8).

The differences in thermal stability between $D 1_{\text {anaerobic }}$ and $D 1_{\text {aerobic }}$ are buffer-dependent. At the optimal pH, D1 $1_{\text {anaerobic }}$ was more stable than $\mathrm{D} 1_{\text {aerobic }}$ in buffers $\# 3$, \#5 and \#6, while $D 1_{\text {aerobic }}$ was more stable in buffers \#1, \#2, \#4, and \#7. The variability of $T_{m} s$ in different conditions but with the same $p H$ value are higher for $D 1_{\text {aerobic }}$ than for $D 1_{\text {anaerobic }}$ suggesting that the $D 1_{\text {aerobic }}$ is more affected by the buffer components, presumably due to forming protein-buffer complexes in lieu of the cofactor. D $1_{\text {anaerobic }}$ incubated overnight at atmospheric air (and presumably with oxidized, partially decomposed Moco) did not show any major changes in its $T_{m}$ (less than $d T=4^{\circ} \mathrm{C}$ ) (Fig. 8), which suggests that either the Moco is relatively stable when bound to D1 protein or Moco degradation products stabilize the protein efficiently (Fig. 8).

The $\mathrm{D} 1_{\text {aerobic }}$ protein was most stabilized by streptomycin as well as chloride salts of some divalent metal ions, e.g., $\mathrm{ZnCl}_{2}, \mathrm{NiCl}_{2}$, and $\mathrm{CdCl}_{2}$ (Fig. 9 and Supplemental Fig. S4A). The influence of zinc ions on $\mathrm{D} 1_{\text {aerobic }}$ was also noticed in crystallization experiments, as crystals were formed in conditions with zinc salts. Metals are known to affect protein thermal stability and shape, because residues that bind metal often undergo conformational changes upon metal binding [83]. Histidines, cysteines, glutamic acid and aspartic acid most commonly bind to metal ions [84], and metal binding proteins quite often possess characteristic motifs of interaction. Comparative analyses of crystal structures in PDB revealed that zinc and nickel most often bind cysteines or histidines [84]. D1 has 7 histidines and 2 cysteines so there are possible sites of interactions, however, the mode of stabilization needs to be determined as no common metal binding motifs were detected by several servers predicting metal binding sites in protein: IonCom [85], SeqChed [86], ZincExplorer [87] (results not shown). Coincidently, as EXAFS analysis demonstrated that molybdenum in $D 1_{\text {anaerobic }}$ formed Mo-Ni clusters, it is possible that the binding site for divalent transition metals in D1 overlaps with the Moco binding site.

Streptomycin was another compound that stabilized D1 protein (Fig. 9). It is a branched molecule with two guanidinium groups close to each other, resembling a set of two arginines. An RR sequence is a motif characteristic of a twin arginine system (TAT). This motif is recognized by the translocation system and its recognition is blocked by the chaperone until the transported protein matures [32]. It has been shown that other molybdoenzyme maturation chaperones recognize the TAT signal motif directly $[88,89]$. Two arginines present in the $\mathrm{N}$-terminal fragment of metalloproteins are recognized by a chaperone molecule, and then the protein is transported through a membrane. It is likely that the streptomycin's guanidinium groups are recognized in a similar way to arginines and that interaction stabilizes the D1 chaperone. However, no change in D1 $1_{\text {aerobic }}$ stability was observed in the presence of arginine by TSA. We used the streptomycin to carry out the crystallization screens, but we did not observe the improvement on D1 crystallizability.

There was no change in the fluorescence signal when $\mathrm{D} 1_{\text {aerobic }}$ was incubated with $3.5 \mathrm{M}$ urea, $\mathrm{FAD}, 1 \mathrm{M}$ and $3.5 \mathrm{M}$ guanidine, $\mathrm{CoCl}_{2}$, or $\mathrm{CuCl}_{2}$, indicating that the protein may have denatured upon 
mixing with these compounds before the actual measurements. For TCEP, a $T_{m}$ of around $20^{\circ} \mathrm{C}$ was recorded, suggesting strong destabilization effects of this reducing compound on D1 $1_{\text {aerobic }}$ (Supplemental Fig. S5).

Our crystallization trials resulted in several conditions in which crystals were formed (Supplemental Fig. S6). Each of the promising conditions were optimized, but unfortunately, we were unsuccessful at this point in obtaining crystals diffracting better than $9 \AA$. There are several potential reasons why the protein may not form crystals of a quality suitable for successful structure determination. The protein may have a high degree of structural flexibility, or the sample may not be homogenous. In FPLC analysis we observed that $\mathrm{D} 1_{\text {aerobic }}$ changes its oligomerization state upon exposure to oxygen, which is reversible by addition of reducing agent, indicating intramolecular disulfide bridge formation. Although the influence of reducing agents on crystallization experiments was tested, it did not improve the quality of crystals. It is possible that during crystallization process the reducing agent oxidized leading to oxidation of protein cysteines, subsequent formation of disulfide bridges and in consequence to protein oligomerization. SEC FPLC in non-denaturing conditions showed a higher apparent mass of both the monomer and dimer than the mass calculated from the sequence (Fig. 6), while the results from SEC HPLC in denaturing conditions agreed with mass calculated for the monomer and dimer (Fig. 2A). The SEC analysis suggests the elongated shape of the protein or its partial disorder because deviation from the globular shape affects elution time [90]. High protein disorder usually correlates with poor protein crystallizability [91, 92].

Several previous studies showed that GDP can act as a Moco surrogate in Moco-free proteins [68]. The surface signature consistent with the guanine binding site has been also detected in the structure of a D1 homolog [70]. Because the HPLC analysis indicated that D1 $1_{\text {aerobic }}$ was not bound to any UV-VIS absorbing molecule (Fig. 2A), we were interested in determining whether GDP can act as a Moco surrogate. We ran several experiments to detect this putative interaction: simple SEC analysis under native conditions, ITC, and TSA. Addition of the GDP to protein sample did not change its absorbance at $280 \mathrm{~nm}$ (Fig. 7B), indicating that no additional molecule was bound to the protein. No heat of binding was detected when titrating D1 $1_{\text {aerobic }}$ with the GDP using ITC (Fig. 7C), and protein thermal stability of $D 1_{\text {aerobic }}$ was not affected when GDP was added (Fig. 7A). These results suggest that that $D 1_{\text {aerobic }}$ does not bind Moco/MGD through nucleoside fragment alone.

\section{CONCLUSIONS}

An efficient system for molybdenum cofactor production would positively impact analytical, biochemical, and pharmaceutical studies. We developed efficient methods for production and purification of chaperone proteins containing Moco, which would provide a precursor source of Moco and a high amount of protein for further analysis. The EXAFS and TSA results described here provide background for further studies on Moco cofactor assembly and chaperone functions. The optimized method for anaerobic chaperone production presented here was necessary and crucial to develop the system for overexpression of active steroid C25 dehydrogenase (Rugor et al., to be published), validating our divide-and-conquer strategy.

Suggested future directions include development of methods for isolation of Moco from recombinant D1 protein. The purified D1 $1_{\text {anaerobic }}$ protein loaded with Moco can serve as a natural source 
of cofactor for further chemical modifications that possibly can be easily separated from a protein under reducing conditions. Overexpression of chaperone protein alone guarantees that the extracted Moco is not contaminated with other cofactors present in more complex molybdoenzymes. Moreover, the D1 protein can be also used for Moco stabilization by binding to it under various conditions. Future plans may also include further trials in the structure determination to gain more insight into the process of maturation of cofactor-containing multi-subunit proteins. 
Table 1. Composition of buffers used in TSA analysis.

\begin{tabular}{cccc}
\hline $\begin{array}{c}\text { Buffer } \\
\text { number }\end{array}$ & Compound (100mM) & $\begin{array}{c}\text { Mass } \\
\text { ratio }\end{array}$ & Supplier \\
\hline 1 & Succinic acid & 2 & Bioshop (Suc444) \\
& Sigma (S9638) & Sigma (G7126) \\
\hline 2 & Sodium dihydrogen phosphate & 7 & Bioshop (CIT002) \\
& Glycine & 7 & Sigma (H3375) \\
& Citric acid anhydrous & 2 & Sigma (C2885) \\
\hline 3 & HEPES & 3 & Sigma (M1296) \\
& CHES & 4 & Acros Organics (288324) \\
& Malonic acid & Poch (531360115) \\
\hline 4 & Imidazole & Sigma (P1880) \\
& Boric acid & 2 & Sigma (CO250) \\
& Sodium propionate & 3 & Bioshop (BTP501) \\
\hline 5 & Sodium cacodylate & 3 & Poch (805670119) \\
& Bis-Tris propane & 2 & Roth (9140.3) \\
& Sodium acetate & 1 & Bioshop (BIC703) \\
\hline 6 & Bis-Tris & 2 & Sigma (M8307) \\
& Bicine & 1 & Sigma (M8250) \\
& L-Malic & 1 & Bioshop (TRS001) \\
\hline 7 & MES & 1 & Sigma (S4797) \\
& Tris & 1 & Roth (9140.3) \\
& Bis-Tris & 2 & Bioshop (GGL888) \\
\hline
\end{tabular}

Table 2. A list of ligands used in TSA experiments.

\begin{tabular}{cccc}
\hline Group & Compound & Concentration & Supplier \\
\hline Aminoacids & L-Asparagine & $30 \mathrm{mM}$ & Sigma A0884 \\
L-Tryptophan & $30 \mathrm{mM}$ & Sigma 93659 \\
L-Tyrosine & $30 \mathrm{mM}$ & Sigma T3754 \\
L-Leucine & $30 \mathrm{mM}$ & Sigma L8912 \\
L-glutamine & $30 \mathrm{mM}$ & Sigma G8540 \\
L-Phenylalanine & $30 \mathrm{mM}$ & Sigma P2126 \\
L-Histidine & $30 \mathrm{mM}$ & Sigma H6034 \\
L-Methionine & $30 \mathrm{mM}$ & Sigma M5308 \\
L-Cysteine & $30 \mathrm{mM}$ & Sigma C7352 \\
L-Lysine & $30 \mathrm{mM}$ & Acros 173730250 \\
L-Arginine & $30 \mathrm{mM}$ & Sigma A5006 \\
\hline Sugars & $10 \mathrm{mM}$ & Aldrich 158968 \\
& D-D-Glucose & $10 \mathrm{mM}$ & Sigma F0127 \\
& $10 \mathrm{mM}$ & Sigma S3889 \\
D-Sorbitol & $10 \mathrm{mM}$ & Fluka 63582 \\
D-(+)-Mannose & $10 \mathrm{mM}$ & Sigma F2252 \\
& L-(-)-Fucose & &
\end{tabular}




\begin{tabular}{|c|c|c|c|}
\hline & D-(+)-Galactose & $10 \mathrm{mM}$ & Sigma-Aldrich G6404 \\
\hline & D-(+)-Glucosamine hydrochloride & $10 \mathrm{mM}$ & Sigma G4875 \\
\hline & $\alpha$-D-Glucose 1-phosphate disodium & $2 \mathrm{mM}$ & Sigma G7000 \\
\hline & salt hydrate & & \\
\hline & $\alpha-D-G a l a c t o s a m i n e ~ 1-p h o s p h a t e$ & $2 \mathrm{mM}$ & Sigma G5134 \\
\hline \multirow[t]{7}{*}{ Antibiotics } & Apramycin sulfate salt & $10 \mathrm{mM}$ & Sigma A2024 \\
\hline & Ampicillin sodium salt & $10 \mathrm{mM}$ & Sigma-Aldrich A9518 \\
\hline & Paromomycin sulfate salt & $10 \mathrm{mM}$ & Sigma P5057 \\
\hline & Cefuroxime sodium salt & $10 \mathrm{mM}$ & Sigma C4417 \\
\hline & Tetracycline & $10 \mathrm{mM}$ & Sigma 87128 \\
\hline & Streptomycin sulfate salt & $10 \mathrm{mM}$ & Sigma-Aldrich S6501 \\
\hline & Cephalosporin C zinc salt & $10 \mathrm{mM}$ & Sigma 3270 \\
\hline \multirow[t]{8}{*}{ Nucleosides } & $\begin{array}{c}\text { Adenosine } 5^{\prime} \text {-diphosphate sodium } \\
\text { salt }\end{array}$ & $2 \mathrm{mM}$ & Sigma A2754 \\
\hline & $\begin{array}{c}\text { Guanosine } 5 \text { '-triphosphate sodium } \\
\text { salt hydrate }\end{array}$ & $2 \mathrm{mM}$ & Sigma 8877 \\
\hline & $\begin{array}{l}\text { Adenosine } 5^{\prime} \text {-triphosphate } \\
\text { disodium salt hydrate }\end{array}$ & $2 \mathrm{mM}$ & Sigma A7699 \\
\hline & $\begin{array}{c}\text { Adenosine 5'-monophosphate } \\
\text { disodium salt }\end{array}$ & $2 \mathrm{mM}$ & Sigma 01930 \\
\hline & $\begin{array}{c}\text { Guanosine } 5^{\prime} \text {-diphosphate sodium } \\
\text { salt }\end{array}$ & $2 \mathrm{mM}$ & Sigma G7127 \\
\hline & $\begin{array}{c}\text { Cytidine } 5^{\prime} \text {-monophosphate } \\
\text { disodium salt }\end{array}$ & $2 \mathrm{mM}$ & Sigma C1006 \\
\hline & Thymidine 3':5'-cyclic & $2 \mathrm{mM}$ & Sigma T6754 \\
\hline & monophosphate sodium salt & & \\
\hline \multirow[t]{9}{*}{ Cofactors } & $\beta$-Nicotinamide adenine & $2 \mathrm{mM}$ & Sigma-Aldrich N7004 \\
\hline & dinucleotide hydrate & & \\
\hline & $\beta$-Nicotinamide adenine & & \\
\hline & dinucleotide, reduced disodium & $2 \mathrm{mM}$ & Sigma N8129 \\
\hline & salt hydrate & & \\
\hline & $\beta$-Nicotinamide adenine & $2 \mathrm{mM}$ & Sigma N1630 \\
\hline & $\begin{array}{c}\text { dinucleotide } 2^{\prime} \text {-phosphate reduced } \\
\text { tetrasodium salt hydrate }\end{array}$ & & \\
\hline & Flavin adenine dinucleotide & $10 \mathrm{mM}$ & Sigma F6625 \\
\hline & disodium salt hydrate & & \\
\hline \multirow[t]{7}{*}{ CoA and derivatives } & Coenzyme A sodium salt hydrate & $10 \mathrm{mM}$ & Sigma C3144 \\
\hline & Acetyl coenzyme $A$ lithium salt & $10 \mathrm{mM}$ & Sigma A2181 \\
\hline & Palmitoyl coenzyme A lithium salt & $10 \mathrm{mM}$ & Sigma P9716 \\
\hline & Malonyl coenzyme A lithium salt & $10 \mathrm{mM}$ & Sigma M4263 \\
\hline & Isobutyryl coenzyme A lithium salt & $10 \mathrm{mM}$ & Sigma I0383 \\
\hline & DL- $\beta$-Hydroxybutyryl coenzyme A & $10 \mathrm{mM}$ & Sigma H0261 \\
\hline & lithium salt & & \\
\hline \multirow[t]{2}{*}{ Reducing agents } & DL-Dithiothreitol (DTT) & $5 \mathrm{mM}$ & Promega V3155 \\
\hline & 2-Mercaptoethanol & $5 \mathrm{mM}$ & Aldrich M6250 \\
\hline
\end{tabular}




\begin{tabular}{|c|c|c|c|}
\hline & $\begin{array}{l}\text { Tris(2-carboxyethyl)phosphine } \\
\text { hydrochloride (TCEP) }\end{array}$ & $5 \mathrm{mM}$ & Aldrich C4706 \\
\hline \multirow[t]{10}{*}{ Salts } & Sodium chloride & $10 \mathrm{mM}$ & $\begin{array}{l}\text { Fisher Scientific } \\
\quad \mathrm{S} 6403\end{array}$ \\
\hline & Cadmium chloride & $10 \mathrm{mM}$ & Fluka 20906 \\
\hline & Ammonium Molybdate & $10 \mathrm{mM}$ & Fisher Scientific \\
\hline & & & $A-674$ \\
\hline & Zinc chloride & $10 \mathrm{mM}$ & $\begin{array}{l}\text { Sigma-Aldrich } \\
208086\end{array}$ \\
\hline & Nickel(II) chloride hexahydrate & $10 \mathrm{mM}$ & Sigma N5766 \\
\hline & $\mathrm{CoCl}_{2}$ & $10 \mathrm{mM}$ & Sigma C-3169 \\
\hline & $\mathrm{CuCl}_{2}$ & $10 \mathrm{mM}$ & $\begin{array}{l}\text { Sigma-Aldrich } \\
307483\end{array}$ \\
\hline & $\mathrm{MgCl}_{2}$ & $10 \mathrm{mM}$ & J. T. Baker 2444-01 \\
\hline & Ammonium sulfate & $10 \mathrm{mM}$ & Sigma-Aldrich A4915 \\
\hline \multirow[t]{6}{*}{ Denaturating agents } & Urea & $10 \mathrm{mM}$ & $\begin{array}{l}\text { Fisher Scientific U15- } \\
3\end{array}$ \\
\hline & Urea & $1 \mathrm{M}$ & $\begin{array}{l}\text { Fisher Scientific U15- } \\
3\end{array}$ \\
\hline & Urea & $3.5 \mathrm{M}$ & $\begin{array}{l}\text { Fisher Scientific U15- } \\
3\end{array}$ \\
\hline & Guanidine hydrochloride & $10 \mathrm{mM}$ & Sigma G3272 \\
\hline & Guanidine hydrochloride & $1 \mathrm{M}$ & Sigma G3272 \\
\hline & Guanidine hydrochloride & $3.5 \mathrm{M}$ & Sigma G3272 \\
\hline \multirow[t]{9}{*}{ Buffers } & Tris & $100 \mathrm{mM}$ & RPI T60044 \\
\hline & $\begin{array}{c}\text { Tris } 100 \mathrm{mM} 50 \mathrm{mM} \text { sodium } \\
\text { citrate }\end{array}$ & $100 \mathrm{mM} / 50 \mathrm{mM}$ & $\begin{array}{c}\text { RPI T60044 / Sigma } \\
\text { S4641 }\end{array}$ \\
\hline & Tris $100 \mathrm{mM} 50 \mathrm{mM}$ imidazole & $100 \mathrm{mM} / 50 \mathrm{mM}$ & $\begin{array}{l}\text { RPI T60044 / Sigma- } \\
\quad \text { Aldrich } 56750\end{array}$ \\
\hline & HEPES & $100 \mathrm{mM}$ & $\begin{array}{l}\text { Fisher Scientific } \\
\text { BP310 }\end{array}$ \\
\hline & MES & $100 \mathrm{mM}$ & Sigma M3671 \\
\hline & BisTris & $100 \mathrm{mM}$ & Sigma B9754 \\
\hline & BisTris Propane & $100 \mathrm{mM}$ & Sigma B9410 \\
\hline & MOPS & $100 \mathrm{mM}$ & Sigma M1254 \\
\hline & CHES & $100 \mathrm{mM}$ & Sigma C2885 \\
\hline \multirow[t]{5}{*}{ Others } & Glycerol & $20 \%$ & Alfa Aesar A16205 \\
\hline & Caffeine & $2 \mathrm{mM}$ & Sigma-Aldrich C0750 \\
\hline & Adenine hydrochloride & $2 \mathrm{mM}$ & Sigma A8751 \\
\hline & Cytosine & $2 \mathrm{mM}$ & Sigma C3506 \\
\hline & Xanthine & $2 \mathrm{mM}$ & Fluka 95490 \\
\hline
\end{tabular}




\section{ACKNOWLEDGEMENTS}

We thank Przemyslaw J. Porebski for valuable comments and for critically reading of the manuscript. This research was possible through funding from the Marian Smoluchowski Krakow Research Consortium - a Leading National Research Centre KNOW supported by the Polish Ministry of Science and Higher Education. E.N. was supported by the Foundation for Polish Science (FNP). E.N., A.R., and M.S. acknowledge the financial support of the polish institutions: National Centre for Research and Development [grant number LIDER/33/147/L-3/11/NCBR] and National Science Centre [grant number 2012/05/D/ST4/00277]. W.M. and M.P.C. acknowledge the financial support of the National Institutes of Health [grant number R01GM117325]. Research at the University of Saskatchewan was supported by the Natural Sciences and Engineering Research Council of Canada, with other support from a Canada Research Chair (G.N.G.), the Canadian Institutes of Health Research (CIHR) and the Saskatchewan Health Research Foundation (SHRF). Portions of this research were carried out at the Stanford Synchrotron Radiation Lightsource, a Directorate of SLAC National Accelerator Laboratory and an Office of Science User Facility operated for the U.S. Department of Energy Office of Science by Stanford University. The SSRL Structural Molecular Biology Program is supported by the DOE Office of Biological and

Environmental Research, and by the National Institutes of Health, National Center for Research Resources, Biomedical Technology Program (P41RR001209). 


\section{BIBLIOGRAPHY}

1. Kniemeyer, O. \& Heider, J. Ethylbenzene dehydrogenase, a novel hydrocarbon-oxidizing molybdenum/iron-sulfur/heme enzyme. The Journal of biological chemistry (2001) 276, 2138121386, 10.1074/jbc.M101679200.

2. Leimkuhler, S. \& lobbi-Nivol, C. Bacterial molybdoenzymes: old enzymes for new purposes. FEMS microbiology reviews (2016) 40, 1-18, 10.1093/femsre/fuv043.

3. Nilsson, T., Rova, M. \& Smedja Backlund, A. Microbial metabolism of oxochlorates: a bioenergetic perspective. Biochimica et biophysica acta (2013) 1827, 189-197, 10.1016/j.bbabio.2012.06.010.

4. Saltikov, C. W. \& Newman, D. K. Genetic identification of a respiratory arsenate reductase. Proceedings of the National Academy of Sciences of the United States of America (2003) 100, 10983-10988, 10.1073/pnas.1834303100.

5. Feng, C., Tollin, G. \& Enemark, J. H. Sulfite oxidizing enzymes. Biochimica et biophysica acta (2007) 1774, 527-539, 10.1016/j.bbapap.2007.03.006.

6. Hofmann, N. R. Opposing Functions for Plant Xanthine Dehydrogenase in Response to Powdery Mildew Infection: Production and Scavenging of Reactive Oxygen Species. The Plant cell (2016) 28, 1001, 10.1105/tpc.16.00381.

7. Mendel, R. R. \& Hansch, R. Molybdoenzymes and molybdenum cofactor in plants. Journal of experimental botany (2002) 53, 1689-1698,

8. Nishino, T., Okamoto, K., Eger, B. T., Pai, E. F. \& Nishino, T. Mammalian xanthine oxidoreductase - mechanism of transition from xanthine dehydrogenase to xanthine oxidase. The FEBS journal (2008) 275, 3278-3289, 10.1111/j.1742-4658.2008.06489.x.

9. Rajagopalan, K. V. Molybdenum: an essential trace element in human nutrition. Annual review of nutrition (1988) 8, 401-427, 10.1146/annurev.nu.08.070188.002153.

10. Krompholz, N., Krischkowski, C., Reichmann, D., Garbe-Schonberg, D., Mendel, R. R., Bittner, F., Clement, B. \& Havemeyer, A. The mitochondrial Amidoxime Reducing Component (mARC) is involved in detoxification of $\mathrm{N}$-hydroxylated base analogues. Chemical research in toxicology (2012) 25, 2443-2450, 10.1021/tx300298m.

11. Ott, G., Havemeyer, A. \& Clement, B. The mammalian molybdenum enzymes of mARC. Journal of biological inorganic chemistry : JBIC : a publication of the Society of Biological Inorganic Chemistry (2015) 20, 265-275, 10.1007/s00775-014-1216-4.

12. Kaiser, B. N., Gridley, K. L., Ngaire Brady, J., Phillips, T. \& Tyerman, S. D. The role of molybdenum in agricultural plant production. Annals of botany (2005) 96, 745-754, 10.1093/aob/mci226.

13. Warnke, M., Jung, T., Dermer, J., Hipp, K., Jehmlich, N., von Bergen, M., Ferlaino, S., Fries, A., Muller, M. \& Boll, M. 25-Hydroxyvitamin D3 Synthesis by Enzymatic Steroid Side-Chain Hydroxylation with Water. Angew Chem Int Ed Engl (2016) 55, 1881-1884, 10.1002/anie.201510331.

14. Zdunek-Zastocka, E. \& Lips, H. S. Plant molybdoenzymes and their response to stress. Acta Physiologiae Plantarum (2003) 25, 437-452, 10.1007/s11738-003-0026-z.

15. Mendel, R. R. \& Leimkuhler, S. The biosynthesis of the molybdenum cofactors. Journal of biological inorganic chemistry : JBIC : a publication of the Society of Biological Inorganic Chemistry (2015) 20, 337-347, 10.1007/s00775-014-1173-y.

16. Leimkuhler, S., Wuebbens, M. M. \& Rajagopalan, K. V. The History of the Discovery of the Molybdenum Cofactor and Novel Aspects of its Biosynthesis in Bacteria. Coordination chemistry reviews (2011) 255, 1129-1144, 10.1016/j.ccr.2010.12.003. 
17. Leimkuhler, S. The Biosynthesis of the Molybdenum Cofactor in Escherichia coli and Its Connection to FeS Cluster Assembly and the Thiolation of tRNA. Advances in Biology (2014) 2014, 21, 10.1155/2014/808569.

18. Nichols, J. D. \& Rajagopalan, K. V. In vitro molybdenum ligation to molybdopterin using purified components. The Journal of biological chemistry (2005) 280, 7817-7822, 10.1074/jbc.M413783200.

19. Hille, R. The Mononuclear Molybdenum Enzymes. Chemical reviews (1996) 96, 2757-2816,

20. Hanzelmann, P., Hernandez, H. L., Menzel, C., Garcia-Serres, R., Huynh, B. H., Johnson, M. K., Mendel, R. R. \& Schindelin, H. Characterization of MOCS1A, an oxygen-sensitive iron-sulfur protein involved in human molybdenum cofactor biosynthesis. The Journal of biological chemistry (2004) 279, 34721-34732, 10.1074/jbc.M313398200.

21. Pitterle, D. M. \& Rajagopalan, K. V. The biosynthesis of molybdopterin in Escherichia coli. Purification and characterization of the converting factor. The Journal of biological chemistry (1993) 268, 13499-13505,

22. Pitterle, D. M. \& Rajagopalan, K. V. Two proteins encoded at the chlA locus constitute the converting factor of Escherichia coli chIA1. Journal of bacteriology (1989) 171, 3373-3378,

23. L. Presta, M. F., G. Emiliani, R. Fani (2015). Molybdenum Cofactors and Their role in the Evolution of Metabolic Pathways. Springer.

24. Liu, M. T., Wuebbens, M. M., Rajagopalan, K. V. \& Schindelin, H. Crystal structure of the gephyrin-related molybdenum cofactor biosynthesis protein MogA from Escherichia coli. The Journal of biological chemistry (2000) 275, 1814-1822,

25. Levartovsky, D., Lagziel, A., Sperling, O., Liberman, U., Yaron, M., Hosoya, T., Ichida, K. \& Peretz, $\mathrm{H}$. XDH gene mutation is the underlying cause of classical xanthinuria: a second report. Kidney international (2000) 57, 2215-2220, 10.1046/j.1523-1755.2000.00082.x.

26. Veldman, A., Santamaria-Araujo, J. A., Sollazzo, S., Pitt, J., Gianello, R., Yaplito-Lee, J., Wong, F., Ramsden, C. A., Reiss, J., Cook, I., Fairweather, J. \& Schwarz, G. Successful treatment of molybdenum cofactor deficiency type A with cPMP. Pediatrics (2010) 125, e1249-1254, 10.1542/peds.2009-2192.

27. Dermer, J. \& Fuchs, G. Molybdoenzyme that catalyzes the anaerobic hydroxylation of a tertiary carbon atom in the side chain of cholesterol. The Journal of biological chemistry (2012) 287, 36905-36916, 10.1074/jbc.M112.407304.

28. Srivastava, H. S. Regulation of nitrate reductase activity in higher plants. Phytochemistry (1980) 19, 725-733, http://dx.doi.org/10.1016/0031-9422(80)85100-4.

29. Sambasivarao, D. \& Weiner, J. H. Dimethyl sulfoxide reductase of Escherichia coli: an investigation of function and assembly by use of in vivo complementation. Journal of bacteriology (1991) 173, 5935-5943,

30. Iobbi-Nivol, C. \& Leimkuhler, S. Molybdenum enzymes, their maturation and molybdenum cofactor biosynthesis in Escherichia coli. Biochimica et biophysica acta (2013) 1827, 1086-1101, 10.1016/j.bbabio.2012.11.007.

31. Iobbi-Nivol, C. \& Leimkühler, S. Molybdenum enzymes, their maturation and molybdenum cofactor biosynthesis in Escherichia coli. Biochimica et Biophysica Acta (BBA) - Bioenergetics (2013) 1827, 1086-1101, http://dx.doi.org/10.1016/j.bbabio.2012.11.007.

32. Palmer, T. \& Berks, B. C. The twin-arginine translocation (Tat) protein export pathway. Nature reviews. Microbiology (2012) 10, 483-496, 10.1038/nrmicro2814.

33. Natale, P., Bruser, T. \& Driessen, A. J. Sec- and Tat-mediated protein secretion across the bacterial cytoplasmic membrane--distinct translocases and mechanisms. Biochimica et biophysica acta (2008) 1778, 1735-1756, 10.1016/j.bbamem.2007.07.015. 
34. Chiang, Y. R., Ismail, W., Heintz, D., Schaeffer, C., Van Dorsselaer, A. \& Fuchs, G. Study of anoxic and oxic cholesterol metabolism by Sterolibacterium denitrificans. Journal of bacteriology (2008) 190, 905-914, 10.1128/JB.01525-07.

35. Rugor, A., Tataruch, M., Staron, J., Dudzik, A., Niedzialkowska, E., Nowak, P., Hogendorf, A., Michalik-Zym, A., Napruszewska, D. B., Jarzebski, A., Szymanska, K., Bialas, W. \& Szaleniec, M. Regioselective hydroxylation of cholecalciferol, cholesterol and other sterol derivatives by steroid C25 dehydrogenase. Applied microbiology and biotechnology (2016), 10.1007/s00253016-7880-2.

36. Holick, M. F. Resurrection of vitamin D deficiency and rickets. The Journal of clinical investigation (2006) 116, 2062-2072, 10.1172/JCI29449.

37. McDonald, J. G. \& Russell, D. W. Editorial: 25-Hydroxycholesterol: a new life in immunology. Journal of leukocyte biology (2010) 88, 1071-1072, 10.1189/jlb.0710418.

38. Bischoff-Ferrari, H. A., Dawson-Hughes, B., Stocklin, E., Sidelnikov, E., Willett, W. C., Edel, J. O., Stahelin, H. B., Wolfram, S., Jetter, A., Schwager, J., Henschkowski, J., von Eckardstein, A. \& Egli, A. Oral supplementation with 25(OH)D3 versus vitamin D3: effects on 25(OH)D levels, lower extremity function, blood pressure, and markers of innate immunity. Journal of bone and mineral research : the official journal of the American Society for Bone and Mineral Research (2012) 27, 160-169, 10.1002/jbmr.551.

39. Lee, S. Y. High cell-density culture of Escherichia coli. Trends in biotechnology (1996) 14, 98-105, 10.1016/0167-7799(96)80930-9.

40. Partridge, J. D., Scott, C., Tang, Y., Poole, R. K. \& Green, J. Escherichia coli transcriptome dynamics during the transition from anaerobic to aerobic conditions. The Journal of biological chemistry (2006) 281, 27806-27815, 10.1074/jbc.M603450200.

41. Bilous, P. T. \& Weiner, J. H. Proton translocation coupled to dimethyl sulfoxide reduction in anaerobically grown Escherichia coli HB101. Journal of bacteriology (1985) 163, 369-375,

42. Gunsalus, R. P. Control of electron flow in Escherichia coli: coordinated transcription of respiratory pathway genes. Journal of bacteriology (1992) 174, 7069-7074,

43. Ralph, E. T., Guest, J. R. \& Green, J. Altering the anaerobic transcription factor FNR confers a hemolytic phenotype on Escherichia coli K12. Proceedings of the National Academy of Sciences of the United States of America (1998) 95, 10449-10452,

44. Myers, K. S., Yan, H., Ong, I. M., Chung, D., Liang, K., Tran, F., Keles, S., Landick, R. \& Kiley, P. J. Genome-scale analysis of escherichia coli FNR reveals complex features of transcription factor binding. PLoS genetics (2013) 9, e1003565, 10.1371/journal.pgen.1003565.

45. Lazazzera, B. A., Beinert, H., Khoroshilova, N., Kennedy, M. C. \& Kiley, P. J. DNA binding and dimerization of the Fe-S-containing FNR protein from Escherichia coli are regulated by oxygen. The Journal of biological chemistry (1996) 271, 2762-2768,

46. Green, J., Bennett, B., Jordan, P., Ralph, E. T., Thomson, A. J. \& Guest, J. R. Reconstitution of the [4Fe-4S] cluster in FNR and demonstration of the aerobic-anaerobic transcription switch in vitro. The Biochemical journal (1996) 316 ( Pt 3), 887-892,

47. Jervis, A. J., Crack, J. C., White, G., Artymiuk, P. J., Cheesman, M. R., Thomson, A. J., Le Brun, N. E. \& Green, J. The $\mathrm{O} 2$ sensitivity of the transcription factor FNR is controlled by Ser24 modulating the kinetics of [4Fe-4S] to [2Fe-2S] conversion. Proceedings of the National Academy of Sciences of the United States of America (2009) 106, 4659-4664, 10.1073/pnas.0804943106.

48. Wu, S. Y., Rothery, R. A. \& Weiner, J. H. Pyranopterin Coordination Controls Molybdenum Electrochemistry in Escherichia coli Nitrate Reductase. The Journal of biological chemistry (2015) 290, 25164-25173, 10.1074/jbc.M115.665422. 
49. Simala-Grant, J. L. \& Weiner, J. H. Kinetic analysis and substrate specificity of Escherichia coli dimethyl sulfoxide reductase. Microbiology (1996) 142 (Pt 11), 3231-3239, 10.1099/13500872142-11-3231.

50. Rothery, R. A., Grant, J. L., Johnson, J. L., Rajagopalan, K. V. \& Weiner, J. H. Association of molybdopterin guanine dinucleotide with Escherichia coli dimethyl sulfoxide reductase: effect of tungstate and a mob mutation. Journal of bacteriology (1995) 177, 2057-2063,

51. Graslund, S., Nordlund, P., Weigelt, J., Hallberg, B. M., Bray, J., Gileadi, O., Knapp, S., Oppermann, U., Arrowsmith, C., Hui, R., Ming, J., dhe-Paganon, S., Park, H. W., Savchenko, A., Yee, A., Edwards, A., Vincentelli, R., Cambillau, C., Kim, R., Kim, S. H., Rao, Z., Shi, Y., Terwilliger, T. C., Kim, C. Y., Hung, L. W., Waldo, G. S., Peleg, Y., Albeck, S., Unger, T., Dym, O., Prilusky, J., Sussman, J. L., Stevens, R. C., Lesley, S. A., Wilson, I. A., Joachimiak, A., Collart, F., Dementieva, I., Donnelly, M. I., Eschenfeldt, W. H., Kim, Y., Stols, L., Wu, R., Zhou, M., Burley, S. K., Emtage, J. S., Sauder, J. M., Thompson, D., Bain, K., Luz, J., Gheyi, T., Zhang, F., Atwell, S., Almo, S. C., Bonanno, J. B., Fiser, A., Swaminathan, S., Studier, F. W., Chance, M. R., Sali, A., Acton, T. B., Xiao, R., Zhao, L., Ma, L. C., Hunt, J. F., Tong, L., Cunningham, K., Inouye, M., Anderson, S., Janjua, H., Shastry, R., Ho, C. K., Wang, D., Wang, H., Jiang, M., Montelione, G. T., Stuart, D. I., Owens, R. J., Daenke, S., Schutz, A., Heinemann, U., Yokoyama, S., Bussow, K. \& Gunsalus, K. C. Protein production and purification. Nature methods (2008) 5, 135-146, 10.1038/nmeth.f.202.

52. Sivashanmugam, A., Murray, V., Cui, C., Zhang, Y., Wang, J. \& Li, Q. Practical protocols for production of very high yields of recombinant proteins using Escherichia coli. Protein science : $a$ publication of the Protein Society (2009) 18, 936-948, 10.1002/pro.102.

53. Bertero, M. G., Rothery, R. A., Palak, M., Hou, C., Lim, D., Blasco, F., Weiner, J. H. \& Strynadka, N. C. Insights into the respiratory electron transfer pathway from the structure of nitrate reductase A. Nature structural biology (2003) 10, 681-687, 10.1038/nsb969.

54. Blasco, F., Dos Santos, J. P., Magalon, A., Frixon, C., Guigliarelli, B., Santini, C. L. \& Giordano, G. $\mathrm{NarJ}$ is a specific chaperone required for molybdenum cofactor assembly in nitrate reductase $A$ of Escherichia coli. Molecular microbiology (1998) 28, 435-447,

55. Stevens, C. M. \& Paetzel, M. Purification of a Tat leader peptide by co-expression with its chaperone. Protein expression and purification (2012) 84, 167-172, 10.1016/j.pep.2012.05.002.

56. Ilbert, M., Mejean, V., Giudici-Orticoni, M. T., Samama, J. P. \& lobbi-Nivol, C. Involvement of a mate chaperone (TorD) in the maturation pathway of molybdoenzyme TorA. The Journal of biological chemistry (2003) 278, 28787-28792, 10.1074/jbc.M302730200.

57. Eschenfeldt, W. H., Lucy, S., Millard, C. S., Joachimiak, A. \& Mark, I. D. A family of LIC vectors for high-throughput cloning and purification of proteins. Methods Mol Biol (2009) 498, 105-115, 10.1007/978-1-59745-196-3_7.

58. Minor, W., Cymborowski, M., Otwinowski, Z. \& Chruszcz, M. HKL-3000: the integration of data reduction and structure solution--from diffraction images to an initial model in minutes. $D$ 9305878 (2006) 62, 859-866, 10.1107/S0907444906019949.

59. Nettleship, J. E., Brown, J., Groves, M. R. \& Geerlof, A. Methods for protein characterization by mass spectrometry, thermal shift (ThermoFluor) assay, and multiangle or static light scattering. Methods Mol Biol (2008) 426, 299-318, 10.1007/978-1-60327-058-8_19.

60. George, G. N. (2017). Molybdenum and Tungsten Enzymes: Spectroscopic and Theoretical Investigations, pp. 121-167: The Royal Society of Chemistry.

61. Cramer S.P., T. O., M. Yocum M., George G.N. A 13-element Ge detector for fluorescence EXAFS. Nuclear Instruments and Methods in Physics Research Section A (1988) 266, 586-591, 10.1016/0168-9002(88)90449-4. 
62. George G.N., G. R. M., Prince R.C., Rajagopalan K. V. The Molybdenum Site of Sulfite Oxidase: A Comparison of Wild-Type and the Cysteine 207 to Serine Mutant Using X-ray Absorption Spectroscopy. J. Am. Chem. Soc., (1996) 118, 8588-8592, 10.1021/ja961218h.

63. Rehr J.J., M. d. L. J., Zabinsky S. I., Albers R. C. Theoretical x-ray absorption fine structure standards. J. Am. Chem. Soc., (1991) 113, 5135-5140, 10.1021/ja00014a001.

64. Pinske, C., Bonn, M., Kruger, S., Lindenstrauss, U. \& Sawers, R. G. Metabolic deficiences revealed in the biotechnologically important model bacterium Escherichia coli BL21(DE3). PloS one (2011) 6, e22830, 10.1371/journal.pone.0022830.

65. Bray, R. C., Adams, B., Smith, A. T., Bennett, B. \& Bailey, S. Reversible dissociation of thiolate ligands from molybdenum in an enzyme of the dimethyl sulfoxide reductase family. Biochemistry (2000) 39, 11258-11269,

66. Kutzler, F. W., Scott, R. A., Berg, J. M., Hodgson, K. O., Doniach, S., Cramer, S. P. \& Chang, C. H. Single-Crystal Polarized X-Ray Absorption-Spectroscopy - Observation and Theory for (Moo2s2)2-. Journal of the American Chemical Society (1981) 103, 6083-6088, Doi 10.1021/Ja00410a016.

67. Pushie, M. J., Cotelesage, J. J., Lyashenko, G., Hille, R. \& George, G. N. X-ray absorption spectroscopy of a quantitatively $\mathrm{Mo}(\mathrm{V})$ dimethyl sulfoxide reductase species. Inorganic chemistry (2013) 52, 2830-2837, 10.1021/ic301660e.

68. Arnoux, P., Ruppelt, C., Oudouhou, F., Lavergne, J., Siponen, M. I., Toci, R., Mendel, R. R., Bittner, F., Pignol, D., Magalon, A. \& Walburger, A. Sulphur shuttling across a chaperone during molybdenum cofactor maturation. Nature communications (2015) 6, 6148, 10.1038/ncomms7148.

69. Cherak, S. J. \& Turner, R. J. Influence of GTP on system specific chaperone - Twin arginine signal peptide interaction. Biochemical and biophysical research communications (2015) 465, 753-757, 10.1016/j.bbrc.2015.08.079.

70. Qiu, Y., Zhang, R., Binkowski, T. A., Tereshko, V., Joachimiak, A. \& Kossiakoff, A. The 1.38 A crystal structure of DmsD protein from Salmonella typhimurium, a proofreading chaperone on the Tat pathway. Proteins (2008) 71, 525-533, 10.1002/prot.21828.

71. Newman, J. Novel buffer systems for macromolecular crystallization. D - 9305878 (2004) 60, 610-612, 10.1107/S0907444903029640.

72. Lin, C. W., Wang, P. H., Ismail, W., Tsai, Y. W., El Nayal, A., Yang, C. Y., Yang, F. C., Wang, C. H. \& Chiang, Y. R. Substrate uptake and subcellular compartmentation of anoxic cholesterol catabolism in Sterolibacterium denitrificans. The Journal of biological chemistry (2015) 290, 1155-1169, 10.1074/jbc.M114.603779.

73. Cormen T.H., L. C. E., Rivest R.L., Stein C. (2009). Introduction to Algorithms. Cambridge, Massachusetts: The MIT Press.

74. Niedzialkowska, E., Gasiorowska, O., Handing, K. B., Majorek, K. A., Porebski, P. J., Shabalin, I. G., Zasadzinska, E., Cymborowski, M. \& Minor, W. Protein purification and crystallization artifacts: The tale usually not told. Protein science : a publication of the Protein Society (2016) 25, 720733, 10.1002/pro.2861.

75. Bolanos-Garcia, V. M. \& Davies, O. R. Structural analysis and classification of native proteins from E. coli commonly co-purified by immobilised metal affinity chromatography. Biochimica et biophysica acta (2006) 1760, 1304-1313, 10.1016/j.bbagen.2006.03.027.

76. Mendel, R. R., Alikulov, Z. A. \& Müller, A. J. Molybdenum cofactor in nitrate reductase-deficient tobacco mutants. III. Induction of cofactor synthesis by nitrate. Plant Science Letters (1982) 27, 95-101, http://dx.doi.org/10.1016/0304-4211(82)90076-1.

77. Kaplan, D., Rtoh-Bejerano, N. \& Lips, H. Nitrate reductase as a product-inducible enzyme. European journal of biochemistry / FEBS (1974) 49, 392-398, 
78. Spiro, S. \& Guest, J. R. Adaptive responses to oxygen limitation in Escherichia coli. Trends in biochemical sciences (1991) 16, 310-314,

79. Self, W. T., Grunden, A. M., Hasona, A. \& Shanmugam, K. T. Transcriptional regulation of molybdoenzyme synthesis in Escherichia coli in response to molybdenum: ModE-molybdate, a repressor of the modABCD (molybdate transport) operon is a secondary transcriptional activator for the hyc and nar operons. Microbiology (1999) 145 ( Pt 1), 41-55, 10.1099/13500872-145-141.

80. George, G. N., Pickering, I. J., Harris, H. H., Gailer, J., Klein, D., Lichtmannegger, J. \& Summer, K. $\mathrm{H}$. Tetrathiomolybdate causes formation of hepatic copper-molybdenum clusters in an animal model of Wilson's disease. Journal of the American Chemical Society (2003) 125, 1704-1705, 10.1021/ja029054u.

81. Søtofte, I. The Crystal Structure of Tetraphenylphosphonium Bis(tetrathiomolybdato)nickelate(II). Acta. Chem. Scand (1976) 30, 157-162, 10.3891/acta.chem.scand.30a-0157.

82. Adams, H., Gardner, H. C., McRoy, R. A., Morris, M. J., Motley, J. C. \& Torker, S. Heterometallic Dithiolene Complexes Formed by Stepwise Displacement of Cyclopentadienyl Ligands from Nickelocene with CpMo(S2C2Ph2)2. Inorganic chemistry (2006) 45, 10967-10975, 10.1021/ic0606227.

83. Arnold, F. H. \& Zhang, J. H. Metal-mediated protein stabilization. Trends in biotechnology (1994) 12, 189-192, 10.1016/0167-7799(94)90081-7.

84. Zheng, H., Chruszcz, M., Lasota, P., Lebioda, L. \& Minor, W. Data mining of metal ion environments present in protein structures. Journal of inorganic biochemistry (2008) 102, 17651776, 10.1016/j.jinorgbio.2008.05.006.

85. Hu, X., Dong, Q., Yang, J. \& Zhang, Y. Recognizing metal and acid radical ion-binding sites by integrating ab initio modeling with template-based transferals. Bioinformatics (2016) 32, 32603269, 10.1093/bioinformatics/btw396.

86. Levy, R., Edelman, M. \& Sobolev, V. Prediction of 3D metal binding sites from translated gene sequences based on remote-homology templates. Proteins (2009) 76, 365-374, 10.1002/prot.22352.

87. Chen, Z., Wang, Y., Zhai, Y. F., Song, J. \& Zhang, Z. ZincExplorer: an accurate hybrid method to improve the prediction of zinc-binding sites from protein sequences. Molecular bioSystems (2013) 9, 2213-2222, 10.1039/c3mb70100j.

88. Coulthurst, S. J., Dawson, A., Hunter, W. N. \& Sargent, F. Conserved signal peptide recognition systems across the prokaryotic domains. Biochemistry (2012) 51, 1678-1686, 10.1021/bi201852d.

89. Kirillova, O., Chruszcz, M., Shumilin, I. A., Skarina, T., Gorodichtchenskaia, E., Cymborowski, M., Savchenko, A., Edwards, A. \& Minor, W. An extremely SAD case: structure of a putative redoxenzyme maturation protein from Archaeoglobus fulgidus at 3.4 A resolution. $D$ - 9305878 (2007) 63, 348-354, 10.1107/S0907444906055065.

90. Uversky, V. N. Use of fast protein size-exclusion liquid chromatography to study the unfolding of proteins which denature through the molten globule. Biochemistry (1993) 32, 13288-13298,

91. Price, W. N., 2nd, Chen, Y., Handelman, S. K., Neely, H., Manor, P., Karlin, R., Nair, R., Liu, J., Baran, M., Everett, J., Tong, S. N., Forouhar, F., Swaminathan, S. S., Acton, T., Xiao, R., Luft, J. R., Lauricella, A., DeTitta, G. T., Rost, B., Montelione, G. T. \& Hunt, J. F. Understanding the physical properties that control protein crystallization by analysis of large-scale experimental data. Nature biotechnology (2009) 27, 51-57, 10.1038/nbt.1514. 
92. Slabinski, L., Jaroszewski, L., Rychlewski, L., Wilson, I. A., Lesley, S. A. \& Godzik, A. XtalPred: a web server for prediction of protein crystallizability. Bioinformatics (2007) 23, 3403-3405, 10.1093/bioinformatics/btm477. 